\title{
ODABIR BILJNIH VRSTA ZA ŠKOLSKI VRT I PLAN VRTLARSKIH AKTIVNOSTI U OŠ RUGVICA
}

\author{
PLANT SPECIES CHOICE FOR SCHOOL YARD \\ AND THE GARDENING ACTIVITIES PLAN FOR PS RUGVICA
}

\author{
Vesna Židovec, Silvija Jusup, M. Poje, Dubravka Dujmović Purgar
}

\section{SAŽETAK}

Školski vrtovi trebali bi proizaći iz sredine u kojoj se nalaze. Predstavljaju mjesta koja služe za boravak učenika u slobodno vrijeme, ali su pogodni i za proučavanje brojnih sadržaja vezanih uz nastavu i izvannastavne aktivnosti. Izuzetno je važno kod učenika razvijati pozitivne psihofizičke osobine, poticati usvajanje novih znanja i vještina u zdravom okruženju. Ovakav pristup učenju i ulozi okoliša u odgoju, trebao bi pobuditi interes za prirodu i stvoriti čim ranije što intimniju vezu učenika i prirode.

Pregledom literature i arhivske građe te intervjuiranjem starijih stanovnika sakupljeni su podaci o biljnim vrstama koje su se nekad tradicionalno uzgajale u vrtovima na području općine Rugvica. Ti podaci, zajedno s podacima o prisutnosti biljnih vrsta školskog dvorišta, poslužili su kao temelj preporuka za odabir vrsta za uređenje okoliša škole. Pomoću literature određena je taksonomska pripadnost, životni oblik i porijeklo inventariziranih vrsta te je predložen niz vrtlarskih aktivnosti primjerenih djeci nižih razreda.

Na području općine Rugvica u prošlosti se živjelo od poljoprivrede, a uz kuće su se nalazili povrtnjaci i voćnjaci. Na okućnicama je bilo i raznolikog ukrasnog bilja. U vrtu OŠ Rugvica determinirano je 17 biljnih porodica i 28 vrsta. Porodice s najvećim brojem vrsta su Pinaceae i Lamiaceae. U vrtu se nalaze i zanimljivi detalji (sjenica, meteorološka kućica, viseći vrt). Za dodavanje sadržaja vrtu predložene su povrtna, voćna, začinsko-ljekovita i tradicijska cvjetna gredica te je osmišljen cjelogodišnji program radionica za djecu za koje bi se materijali uglavnom mogli naći u školskom vrtu i bližem okolišu.

Ključne riječi: okućnica, ruralni prostor, tradicijski vrt, vrtlarske radionice za djecu 


\begin{abstract}
School gardens should come out from the environment in which they are located. There, pupils should spend their free time, but they should be suitable for studying numerous contents related to curricular and extracurricular activities as well. It is extremely important for students to develop positive psychophysical characteristics, encourage the acquisition of new knowledge and skills in a healthy environment. Such approach in learning and the environmental role in education should arouse interest in the natural and create as intimate a connection between students and nature as possible.
\end{abstract}

By reviewing the literature and archives and interviewing elderly residents, data were collected on plant species that were once traditionally grown in gardens in the municipality of Rugvica. The field visit listed the plant species of the school yard, and the literature determined the taxonomic affiliation, life form and origin. Based on the results of the interview and inventory, species for arranging the school environment were proposed, and with the help of the literature, an overview of gardening activities suitable for lower grade children was given.

In the area of Rugvica, in the past, people lived from agriculture, and next to the houses there were vegetable gardens and orchards. There were also a variety of ornamental plants in the backyards. In the garden of the elementary school Rugvica, 17 plant families and 28 species were determined. The families with the largest number of species are Pinaceae and Lamiaceae. In the garden there are also interesting details (gazebo, meteorological house, hanging garden). To add content to the garden, vegetable, fruit, spice-medicinal and traditional flower beds have been proposed, and a year-round program of workshops has been designed for which materials could most often be found in the school garden and the surrounding area.

Keywords: homeyard, rural area, traditional garden, gardening workshops for children

\title{
UVOD
}

Zbog manjka sredstava i vremena većina je školskih vrtova skromno uređena ili uoće nije uređena. Školski okoliš trebao bi biti mjesto stjecanja znanja i vještina, te demonstracije načela održivog razvoja. Obuhvaća prostor izvan školske zgrade (vrt, šetnice, park, parkiralište, igralište, itd.). Može 
zauzimati mnogo četvornih metara, ali može biti i atrijskog tipa. Navedeni okoliš treba doživljavati kao dio cjeline u kojoj se nalazi, te stil i način oblikovanja uskladiti s veličinom prostora, stilom i starošću objekta (Grudiček Kozjak i sur., 2005.).

Školski vrtovi, osim što su ukras i ponos mnogih škola, imaju i važnu edukativno - odgojnu ulogu. Školski vrt treba omogućiti nastavu i provođenje slobodnog vremena na otvorenom te izvannastavne aktivnosti (Anđić, 2016.). Važno je da gospodarski dio bude tehnički i estetski dobro osmišljen, organiziran, pa će takav ispuniti i pedagogijsku funkciju što je osnovna svrha školskog vrta (Slančec i Munjiza, 2007.). Tijekom povijesti mijenjale su se preporuke o potrebnoj veličini i organizaciji školskog vrta, no uvijek je trebao djelovati odgojno (Slačanac i Munjiza, 2007.).

Poželjno je školski vrt povezati s tradicijom mjesta u kojem je škola smještena. Na taj način učenici uz pomoć učitelja i ostalih djelatnika škole mogu proširiti spoznaje o svom zavičaju i običajima, ali i o zavičajnoj mikroregiji i šire (načelo zavičajnosti). Učenici spoznaju zemljopisne odlike, biljni i životinjski svijet, povijest zavičaja, zanimanja ljudi i slično (De Zan, 1999.). Odgojno obrazovni sadržaji izvan učionice kod učenika razvijaju sposobnost kritičkog promatranja, razumijevanje ovisnosti prirode i ljudi, poučavanje znanstvenih načela i upoznavanje kulturne baštine (Borić, 2009.). Prema Cmrečnjak Majstorović (2016.) vrt je najdostupniji primjer funkcioniranja ekosustava i uloga vrta je zainteresirati djecu za održivu proizvodnju. Pojam održivosti se upotrebljava za sveukupno čovjekovo djelovanje na Zemlji tj. kao sposobnost održavanja ravnoteže procesa ili stanja u nekom sustavu (Samuelsson i Kaga, 2008.).

Istraživanja dobrobiti školskog vrta i vrtlarenja analiziraju različite aspekte u životima učenika, ali najviše se spominje spoznaja o zdravoj prehrani, ponašanje učenika i akademska postignuća (Yu, 2012.). Tako Anđić (2016.) ističe razvoj radnih navika i kreativnosti kod učenika, socijalnih i motoričkih vještina, jačanje samopouzdanja i koncentracije, stjecanje odgovornosti prema kulturnoj i prirodnoj baštini, te ekološki i estetski odgoj. Aktivno provedeno slobodno vrijeme u školskom vrtu, ujedno je i borba protiv delikventnog ponašanja (Anđić, 2016.). Učenike je potrebno od nižih razreda osnovne škole navikavati na nastavu u prirodi, osobito jer su danas razvojem tehnologije posebno usmjereni na aktivnosti u zatvorenom (Bogut $i$ sur., 2017.). Planiranjem vrtlarskih aktivnosti djecu je moguće animirati i educirati 
istovremeno, što se pokazalo i kao najbolji način učenja. Financijski faktor, uz kvalitetan plan aktivnosti u vrtu, jedna je od presudnih točaka prilikom uređenja i raznovrsnosti školskog vrta. Kvalitetan plan vrtnih aktivnosti prema Sherman (2010.) treba rezultirati novim vještinama i znanjem, ekološki prihvatljivim načinom života, uzgojem biljaka za kvalitetniju prehranu, povećanjem kvalitete školskog okoliša.

Prve informacije o školskim vrtovima odnosile su se na botaničke vrtove za školske šetnje, sustavno promatranje i kao izvor zornosti u nastavi. Kasnije dobivaju proizvodno-gospodarsku funkciju. Od 1905. postaju opće nastavni ili pedagogijski s ciljem pomoći u nastavi i školi (Munjiza 2003.) te su služili za izvođenje praktične nastave. To su bili pokusni vrtovi pomoću kojih su djeca učila o uzgoju različitih kultura u njihovom kraju. Djeca su aktivno sudjelovala u vrtlarskim radnjama. Sadila su, zalijevala, promatrala razvoj biljaka i plodova, te nosila plodove kućama. Od ranog djetinjstva naučena su raditi zajedno $\mathrm{s}$ prirodom (Kolar-Dimitrijević, 2014.). O uspostavi, razvoju i organizaciji školskih vrtova na području Hrvatske pisali su Schwab (1877.), Trstenjak (1883.), Pirnat (1952.), Skulj (1954.), Munjiza (2003.), Grudiček - Kozjak i sur. (2005.), Slačanac i Munjiza (2007.), Lukaš (2008.).

Općina Rugvica graniči sa Zagrebom na sjeveru, Dugim Selom na istoku, Ivanić Gradom na jugu i na zapadu s općinom Orle i Velikom Goricom. Čine je 23 naselja, a ime je dobila po naselju Rugvica koje je smješteno u centralnom dijelu općine. Rugvica je dobila ime po horugvi, staroslavenskom izrazu za zastavu, koja je označavala luku (Kirin, 2016.). Pozicija sela učinila ga je gospodarskim, političkim i obrazovnim središtem (Općina Rugvica). OŠ Rugvica, kao nova, modernija ustanova otvara svoja vrata 1969. godine. U nadolazećim godinama škola postaje suvremena odgojno obrazovna ustanova. Školska godina 2004/2005. je bila značajna i zapamćena u povijesti škole budući da je tada nastava započela u novoj zgradi, a na mjestu stare zgrade je nakon nekoliko godina izgrađena sportska dvorana.

Cilj ovog istraživanja bio je utvrditi koje su se biljne vrste nekad uzgajale $u$ vrtovima općine Rugvica, prema sjećaju starijih stanovnika; inventarizirati biljne vrste vrta OŠ Rugvica; za inventarizirane vrste odrediti: taksonomsku pripadnost, porijeklo, životni oblik; predložiti biljne vrste za uzgoj u školskom vrtu; predložiti cjelogodišnji program radionica u školskom vrtu za učenike nižih razreda. 
Vesna Židovec i sur.: Odabir biljnih vrsta za školski vrt

i plan vrtlarskih aktivnosti u OŠ Rugvica

\section{MATERIJAL I METODE}

Općina Rugvica je smještena u Zagrebačkoj županiji i čine je 23 naselja. Prostire se na 9373 ha na kojem, prema popisu stanovništa iz 2011., živi 7871 stanovnik. Od toga radno sposobno stanovništvo čini $68,91 \%$.

Prostor Općine Rugvica ima osobine umjerenih klima kontinentalnog tipa s toplim ljetima i umjereno hladnim zimama. Prosječno godišnje padne oko 900$1000 \mathrm{~mm}$ padalina, a godišnja količina padalina smanjuje se od zapada prema istoku. Najviše padalina ima u kasno proljeće, rano ljeto i jesen, a najmanje u zimi i rano proljeće. Oborine su tijekom godine raspoređene tako da najviše padalina ima u mjesecu lipnju, a zatim u listopadu ili studenome. S prosječno 47 vedrih i 130 oblačnih dana godišnje, to je relativno oblačno područje.

Općina Rugvica se kreće u pojasu od 100 do 105 m/nv. Nizine zauzimaju čitavu površinu Općine.

Prema inženjersko-geološkoj karti Zagrebačke županije, područje Općine se sastoji od koherentnog i nekoherentnog tla. Koherentno ili sitnozrno tlo je vezano tlo kao što su glina, prašina i les, a nekoherentno je krupnozrno nevezano tlo kao što su pijesak, šljunak odnosno njihove mješavine te prirodne kamene drobine.

Od ukupne površine Općine, najviše otpada na šumske i poljoprivredne površine. Prema pogodnosti za obradu, izdvojene su tri skupine tala. Prva skupina obuhvaća osobito vrijedno obradivo tlo koje zauzima najveći dio područja uz tok Save. Druga skupina, ostala obradiva tla, nalazi se na istočnom dijelu Općine. Vrijedna obradiva tla i ostala poljoprivredna tla, šume i šumsko zemljište rasprostranjeni su po čitavoj Općini (Općina Rugvica).

U svrhu izrade ovog rada provedeno je terensko istraživanje na području Općine Rugvica. Intervjuiranjem starijih stanovnika Rugvice utvrđeno je koje su se biljne vrste tradicionalno uzgajale u predvrtovima i bližoj okolici. Istraživanje je provedeno u periodu u ožujki i travnju 2017. godine.

Intervjuirane su četiri gospođe starije od 60 godina, koje su se prisjetile nekadašnjeg života, okućnica, običaja, biljaka i njihove primjene. Ispitanice su odgovarale na pitanja o načinu života, biljnim vrstama koje su se uzgajale, na okućnicama; namjeni, načinu održavanja, organizacije i uređenja okućnice; stazama i ogradama unutar i oko okućnice. 
Biljne su vrste prikazane u tablici. Za svaku vrstu navedeni su: latinsko ime porodice, vrste, narodni naziv, porijeklo i životni oblik.

Za determinaciju biljaka i nomenklaturu vrsta korištena je sljedeća literatura: Geoff i sur. (2004.), Brickell (2006.), Ogrizović (1982.), te baza podataka Flora Croatica Database.

Podaci o geografskom porijeklu su preuzeti iz: Geoff i sur. (2004.) i baze podataka Flora Croatica Database. Za označavanje geografskog porijekla korištene su oznake: $\mathrm{AF}=$ Afrika, $\mathrm{AZ}=$ Azija, $\mathrm{EU}=$ Europa, J.AM = Južna Amerika, SJ.AM = Sjeverna Amerika i SR.AM = Srednja Amerika.

Prijedlog vrtlarskih aktivnosti predstavljen je kroz aktivnosti tijekom godine, vezano uz godišnja doba. Kao izvori prijedloga korištena je literatura: Arendt (2014.), Benyovsky Šoštarić (2013.), Bull (2003.), Leitzgen i sur. (2013.), Thörn (2016.), Tommes i Roß (2002.).

\section{REZULTATI I RASPRAVA}

Intervju

Razgovor s intervjuiranim gospođama proveden je u njihovim domovima. Na temelju upita dobivene su informacije o nekadašnjem načinu života, izgledu posavskih kuća, povrtnjacima, voćnjacima i ukrasnim biljkama u vrtovima i van njih.

Gospođa Marica govori: Kuća je bila drvena, unutra je stol, klupe, peć, ormari, steklenak (vitrina), jedna soba u kojoj se spavalo, koperte (pokrivači), narodna nošnja. Baka je nosila bijelo. To je značilo žalost, nosilo se bijelo nakon smrti bliske osobe. Na glavi je obavezno bila peča, onda prsnak i opanci. U štalama je bilo četiri do pet krava, kobile koje su se ždrebile svaku godinu. Na pašu su se izvodili od travnja, svinje na jesen na žirenje. Djeca su ih vodila. Kad su vrbe pustile lišće, muži su išli odsjekati vrbe debljine palca. Od debljeg prutja su se radili kolci. Od toga se radila ograda. Kolac se zabijao u zemlju svakih $1-1,5 \mathrm{~m}$ oko dvorišta, a i vrtovi su se ograđivali iza kuće i štale. 60-ih godina podižu se tarabe. Pilari iz Bosne su pokretnim pilama pilali građu za krovište i stupove i letvice visoke oko $1-1,2 \mathrm{~m}$. Ispred kuće je bio mali vrt sa cvijećem, bilo ga je po putevima, po dvorištu. U vrtu ima ljubičica, ne kao danas divlje, nego krupne i mirisne. Bijele su dolazile kasnije. Za vrijeme ljetnih vrućina nije bilo nego ruža. U povrtnjaku je bio krumpir, bob, grašak, 
lučice, slatki luk, zelje, mahune, kušćerak, vugorek (krastavac) za variva, salatu, sitni za zimnicu, paprika sa zeljem se spremala za zimnicu, paradajz. Ispod streha sušili su se duhan, sirak za metle, sir, a luk i češnjak na tavanu.

Blagdani i slavlja su bili obilježeni određenim biljnim vrstama. Prema Kirin (2016.) su se na Cvjetnicu u crkvu nosile grančice drijena, imele (lepka) i bršljana. Za Uskrs su se palili krijesovi. Pleli su se vijenci od cvijeća i zelenila koji su se stavljali kravama na rogove. Brali su se grguri koji su stajali u vazi na stolu. Već u ožujku su u vrtu cvali zumbuli, mirisali klinčeki (Dianthus spp.), trojački (Peonia officinalis), srčeka (Dicentra spectabilis) i turski karanfili. Uz kuće su cvali jorgovani, a u loncima su bile posađene belagonije (Pelargonium spp.) i asparagus (Asparagus sp.). Za Prvi maj se na ulazu u dvorište nalazio lucen (slavoluk) od grana jablana, lipe i jorgovana. Tijelovo je bilo obilježeno velikom procesijom tijekom koje su djevojčice nosile košare s laticama božura i posipale put kojim se prolazilo. Djeca su na poseban način obilježavala Ivanje. Ubrali bi cvijet ivančice i stavili ga u kup sijena u smjeru istok - zapad. Stavljao se po jedan cvijet za svakog člana obitelji, a vjerovalo se da će onaj čije cvijeće najbolje izgleda na dan Ivanja, živjeti najduže. Prva Pričest se primala u desetoj godini, u lipnju. Djevojčice su nosile cvjetne vjenčiće ili šlajere. Često su u ruci imali ljiljan. Svadbe su najčešće bile u studenom. Za svadbu su mladenke imale buket bijelog cvijeća koje je nekad bilo i umjetno ili napravljeno od papira. Za groblje su se pleli vijenci od katarinki (razne krizanteme), raznog zelenila (bušpan, odnosno šimšir) i roži tj. cvjetova napravljenih od krep papira. Vošćenje je bio postupak pri kojem su se papirnati cvjetovi umakali u rastopljeni vosak kako bi bili trajniji i čvršći.

O izgledu kuće i okućnice Kirin (2016.) navodi: Posavska hiža ili iža (kuća za stanovanje s podrumom) je često bila zaštićena brajdama (zasađeni trsovi vinove loze) ili jojerom (orah) koji je morao biti u svakom dvorištu. Uz kuću je često bila kuvarna (manja zgrada, često bez prozora), a uz kuvarnu je bila i krušna peć. U dvorištu je bila smještena i štala i štagel (dio koji se nastavljao uz staju i u koji su se spremala kola). Kukurižnak služi se spremanje kukuruza, kokošinec za perad i svinec, mala i niska nastamba za svinje. Svaka je imala svoj kotec tj. odvojeni prostor. U dvorištu je bio zdenec (bunar) uz koji je bila kopajna gdje se naljevala voda za blago (stoku). Mnogi su imali čigu, drveni stup pomoću kojeg se vadila voda. Iza staje se nalazio tor, ograđeni prostor gdje su se ljeti puštale svinje, jele pokošenu travu i kalile se, valjale u blatu kako bi se rashladile. Uz tor je bio vočnak (voćnjak). U voćnjacima su bile marelice, kruške, jabuka kožnanika, šljive, trešnje, itd. Ispred kuće ili uz nju nalazili su se 
Vesna Židovec i sur.: Odabir biljnih vrsta za školski vrt i plan vrtlarskih aktivnosti u OŠ Rugvica

vrtovi u kojima su češto bili čelinaki (pčelinjaci). U vrtu ispred kuće je bilo ukrasnog i ljekovitog bilja. Veličina i izgled kuće i okućnice ovisio je o financijskim mogućnostima gospodara.

Inventarizacija

Od ukupno 28 biljnih vrsta u školskom vrtu, najzastupljenija porodica je bila Pinaceae s ukupno pet različitih vrsta (tablica 1.). Najbrojnije je drveće koje broji 13 različitih vrsta, odnosno 46\%. U školskom okolišu nema zastupljenih voćaka ni povrtnih kultura. Stoga je njegova funkcija prvenstveno dekorativna i praktična (drveće koje stvara hlad, živica koja štiti školski okoliš od prometnice).

Tablica 1. Biljne vrste u školskom vrtu OŠ Rugvica

Table 1 Plant species in PS Rugvica garden

\begin{tabular}{|c|c|c|c|c|}
\hline \multicolumn{5}{|c|}{$\begin{array}{l}\text { BILJNE VRSTE U ŠKOLSKOM VRTU OŠ RUGVICA } \\
\text { /PLANT SPECIES IN SCHOOL GARDEN OF PS RUGVICA }\end{array}$} \\
\hline $\begin{array}{l}\text { PORODICA/ } \\
\text { FAMILY }\end{array}$ & VRSTA/SPECIES & $\begin{array}{l}\text { NAZIV/ } \\
\text { NAME }\end{array}$ & $\begin{array}{l}\text { PORIJEKO/ } \\
\text { ORIGIN }\end{array}$ & $\begin{array}{l}\text { KATEGORIJA/ } \\
\text { CATEGORY }\end{array}$ \\
\hline Aizoaceae & $\begin{array}{l}\text { Delosperma cooperi } \\
\text { (Hook.f.) L. Bolus }\end{array}$ & Pustinjska ruža & $\mathrm{AF}$ & $\begin{array}{l}\text { Puzajući } \\
\text { sukulent }\end{array}$ \\
\hline Asteraceae & $\begin{array}{l}\text { Santolina } \\
\text { chamaecyparissus } \mathrm{L} .\end{array}$ & Svetolin & EU & Grm \\
\hline Begoniaceae & Begonia semperflorens $\mathrm{L}$. & Begonija & J. AM. & Trajnica \\
\hline Berberidaceae & $\begin{array}{l}\text { Berberis thunbergii } \mathrm{f} . \\
\text { Atropurpurea }\end{array}$ & Žutika & $\mathrm{AZ}$ & Grm \\
\hline \multirow[t]{2}{*}{ Caprifoliaceae } & Viburnum opulus L. & $\begin{array}{l}\text { Snježne kugle } \\
\text { (crvena hudika) }\end{array}$ & $\mathrm{AF}, \mathrm{AZ}, \mathrm{EU}$ & Grm \\
\hline & $\begin{array}{l}\text { Lonicera nitida } \text { E.H. } \\
\text { Wilson }\end{array}$ & $\begin{array}{c}\text { Sjajna } \\
\text { kozokrvina }\end{array}$ & AZ. & Grm \\
\hline Cupressaceae & Thuja occidentalis L. & Američka tuja & SJ. AM. & Stablo \\
\hline Fagaceae & $\begin{array}{l}\text { Fagus sylvatica } \mathrm{f} . \\
\text { purpurea }\end{array}$ & Bukva & EU & Stablo \\
\hline \multirow{4}{*}{ Lamiaceae } & $\begin{array}{l}\text { Lavandula } \\
\text { angustifolia Mill. }\end{array}$ & Lavanda & EU & Grm \\
\hline & Origanum majorana L. & Mažuran & AZ. & Grm \\
\hline & Mentha $\mathrm{x}$ piperita $\mathrm{L}$. & $\begin{array}{l}\text { Paprena } \\
\text { metvica }\end{array}$ & $\begin{array}{l}\text { AZ., EU., J. } \\
\text { AM, SJ. AM. }\end{array}$ & Trajnica \\
\hline & Rosmarinus officinalis L. & Ružmarin & EU & Grm \\
\hline Oleaceae & Ligustrum vulgare $\mathrm{L}$. & Kalina & $\mathrm{AF}, \mathrm{AZ}, \mathrm{EU}$ & Grm \\
\hline
\end{tabular}


Vesna Židovec i sur.: Odabir biljnih vrsta za školski vrt i plan vrtlarskih aktivnosti u OŠ Rugvica

\begin{tabular}{|c|c|c|c|c|}
\hline \multirow{5}{*}{ Pinaceae } & $\begin{array}{l}\text { Pinus wallichiana A.B. } \\
\text { Jacks. }\end{array}$ & $\begin{array}{c}\text { Himalajski } \\
\text { borovac }\end{array}$ & $\mathrm{AZ}$ & Stablo \\
\hline & Picea pungens Engelm. & Srebrna smreka & SJ. AM. & Stablo \\
\hline & $\begin{array}{l}\text { Picea glauca } \\
\text { (Moench) Voss } \\
\end{array}$ & $\begin{array}{c}\text { Kanadska } \\
\text { smreka }\end{array}$ & SJ. AM. & Stablo \\
\hline & $\begin{array}{l}\text { Picea omorika } \\
\text { (Pančić) Purk. }\end{array}$ & $\begin{array}{c}\text { Pančićeva } \\
\text { omorika }\end{array}$ & EU & Stablo \\
\hline & Picea abies (L.) H. Karst & Obična smreka & EU & Stablo \\
\hline Platanaceae & Platanus occidentalis L. & $\begin{array}{c}\text { Američka } \\
\text { platana }\end{array}$ & $\begin{array}{l}\text { SJ. AM., SR. } \\
\text { AM. }\end{array}$ & Stablo \\
\hline Portulacaceae & $\begin{array}{l}\text { Portulaca } \\
\text { grandiflora Hooker }\end{array}$ & Prkos & J. AM & $\begin{array}{c}\text { Jednogodišnja } \\
\text { vrsta }\end{array}$ \\
\hline \multirow{3}{*}{ Rosaceae } & \begin{tabular}{|l|} 
Photinia glabra \\
(Thunb) Franch., Sav.
\end{tabular} & Fotinija & SJ. AM. & Grm \\
\hline & Rosa sp. & Ruža & $\mathrm{AZ}$ & Grm \\
\hline & $\begin{array}{l}\text { Eriobotrya japonica } \\
\text { (Thunb.) Lindl. } \\
\end{array}$ & Nešpula & $\mathrm{AZ}$ & Stablo \\
\hline Rubiaceae & Galium aparine $\mathrm{L}$. & $\begin{array}{l}\text { Ljepljiva } \\
\text { broćika }\end{array}$ & $\begin{array}{l}\text { AZ., EU., SJ. } \\
\text { AM. }\end{array}$ & $\begin{array}{c}\text { Jednogodišnja } \\
\text { vrsta }\end{array}$ \\
\hline Salicaceae & Salix babylonica L. & Žalosna vrba & $\mathrm{AZ}$ & Stablo \\
\hline \multirow[b]{2}{*}{ Sapindaceae } & Acer platanoides $\mathrm{L}$. & Javor mliječ & AZ., EU. & Stablo \\
\hline & \begin{tabular}{|l|} 
Koelreuteria \\
paniculata Laxm. \\
\end{tabular} & Kelreuterija & AZ. & Stablo \\
\hline Tiliaceae & Tilia cordata Mill. & Lipa & AZ. & Stablo \\
\hline
\end{tabular}

Posebno se ističe vrsta Salix babylonica koja je, kao soliter, smještena na sjevernoj strani školskog dvorišta (Slika 1.). Kalina, Ligustrum vulgare je u funkciji živice, koja je uredna i održavana (Slika 2.). Južna strana dvorišta je u debelom hladu zahvaljujući drvoredu javora, Acer platanoides s jedne strane (Slika 3.), te platane, Platanus occidentalis i lipe, Tilia cordata s druge strane (Slika 4).

Školski vrt ima nekoliko zanimljivih detalja, a to su: viseći vrt (Slika 5), posude za cvijeće izrađene od automobilskih guma (Slika 6.), meteorološka kućica i sjenica (Slika 7.), znak s informacijama o reciklaži. 
Vesna Židovec i sur.: Odabir biljnih vrsta za školski vrt i plan vrtlarskih aktivnosti u OŠ Rugvica

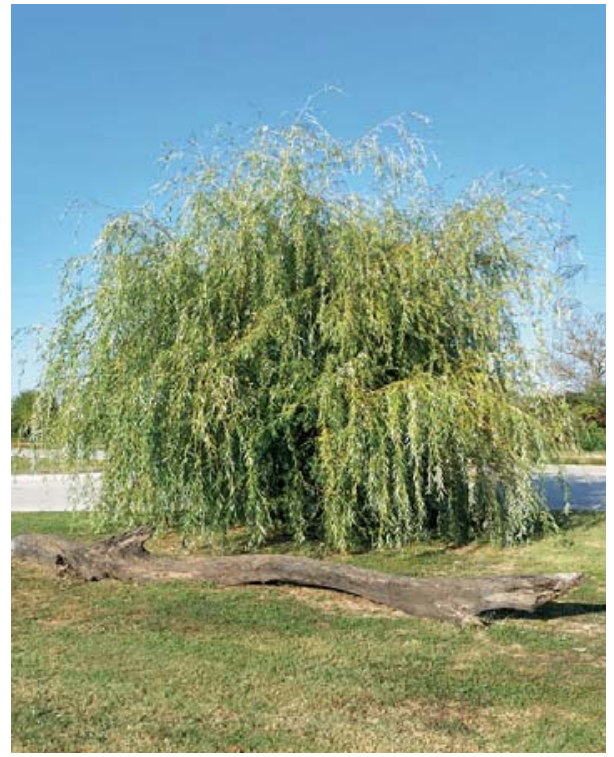

Slika 1. Salix babylonica $L$. (Foto: Jusup 2018)

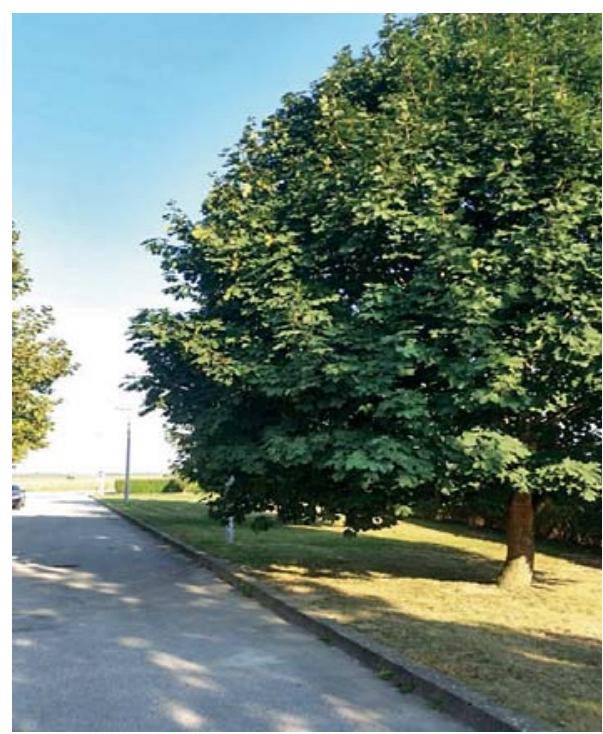

Slika 3. Acer platanoides (Foto: Jusup 2018)

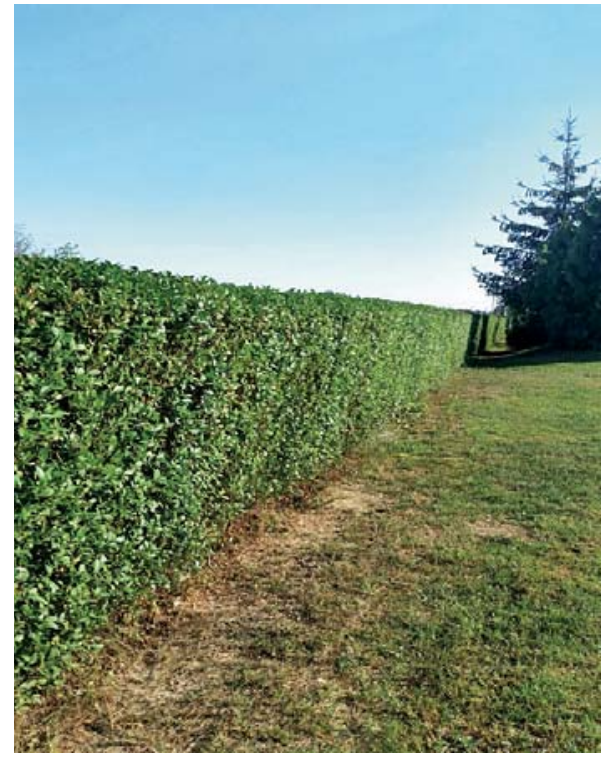

Slika 2. Ligustrum vulgare L. (Foto: Jusup 2018)

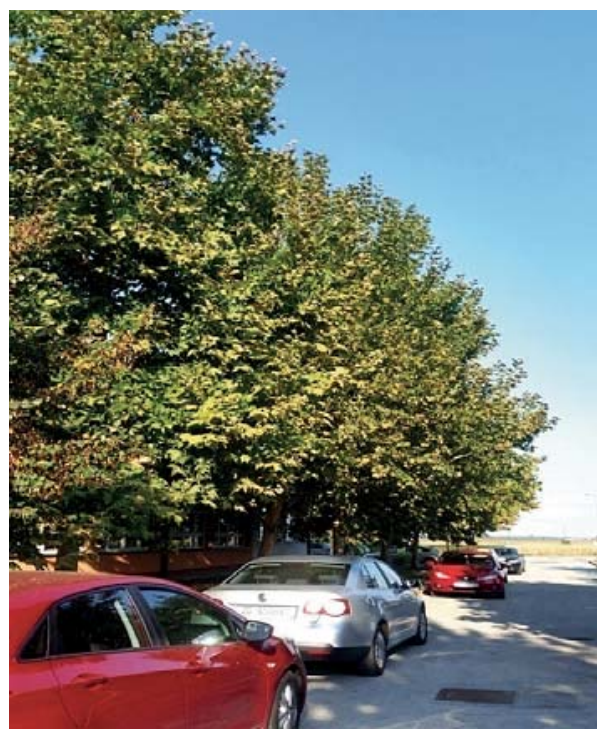

Slika 4. Platanus occidentalis L. $i$ Tilia cordata Mill. (Foto: Jusup 2018) 
Vesna Židovec i sur.: Odabir biljnih vrsta za školski vrt i plan vrtlarskih aktivnosti u OŠ Rugvica

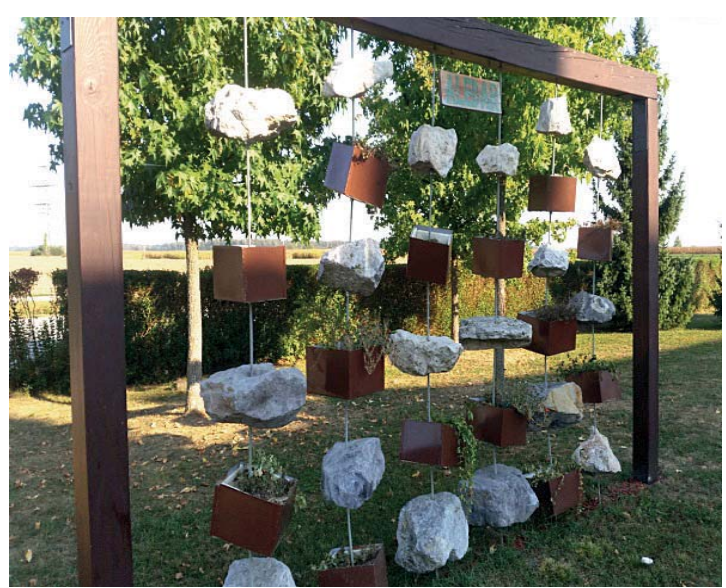

Slika 5. Viseći vrt

(Foto: Jusup 2018)

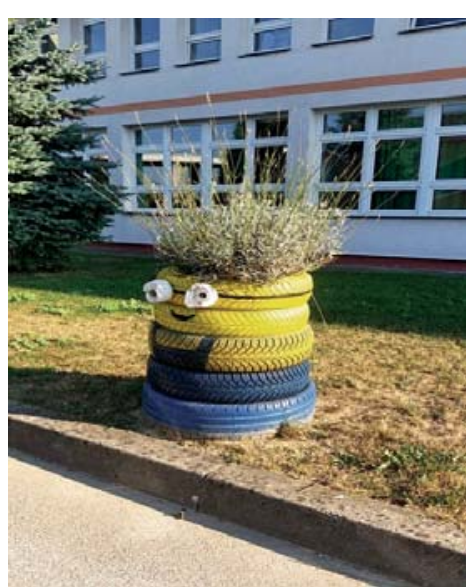

Slika 6. Posude za cvijeće od gume (Foto: Jusup 2018)

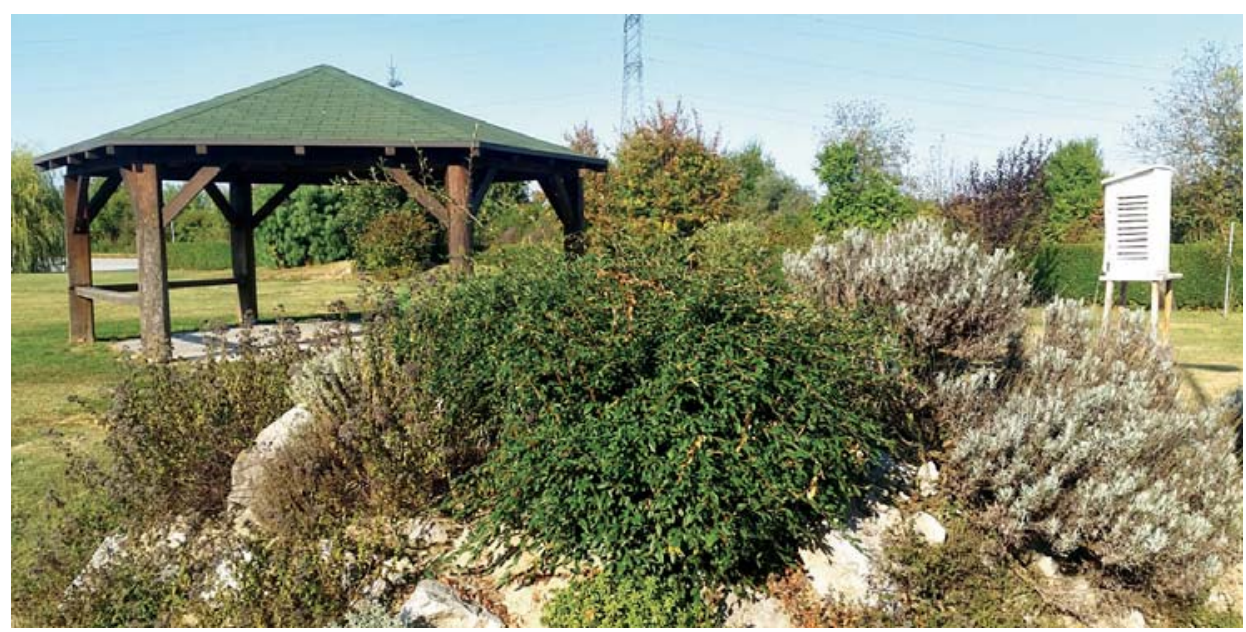

Slika 7. Metorološka kućica i sjenica (Foto: Jusup 2018)

Proučavanjem novijih istraživanja, zapaža se promjena shvaćanja školskog vrta u odnosu na 19. stoljeće kad je naglasak prema Trstenjak (1883.) bio na gospodarskoj funkciji. Prema istraživanju koje su proveli Grudiček-Kozjak i sur. (2005) na području Varaždina ističe se, ne samo dekorativna funkcija vrta, već njegova edukativna i praktična uloga te pozitivan učinak na uređenost školskog okoliša. Grudiček-Kozjak i sur. (2005.) smatraju kako uređenje školskog okoliša mora omogućiti izvođenje školskih radionica i školskih 
sekcija. Ističu se dendrološke vrste, pojedine su zabilježene i u OŠ Rugvica (Picea omorika, Fagus sylvatica f. Purpurea). Njihova funkcija je: smanjenje buke, stvaranje hlada, povoljnije mikroklime i smanjivanje onečišćenja, ublažava se dominacija školske zgrade i postiže se prirodno okruženje. S obzirom na pojačan promet, bitno je da školski okoliš ima dobro održavanu živicu koja pruža fizičku granicu između prometnice ili drugog vanjskog prostora uz školu. Cvjetne vrste se odabiru prema tradiciji kraja u kojem se škola nalazi, ali važan je i cjelokupni vizualni dojam. Trajnice su praktičnije od jednogodišnjih i dvogodišnjih vrsta jer zahtjevaju manje brige.

Ipak, zanimljiva su istraživanja školskih vrtova u urbanim sredinama gdje je zabilježen veći broj utilitarnih vrsta (Jambrek, (2017.), Horvatić, (2018.)) dok su u sredinama gdje je prisutniji ruralni krajobraz i način života, utilitarne vrste gotovo posve zanemarene (Pirić, 2016.). Istraživanjem na području Novog Zagreba, Jambrek (2017.) je utvrdila da na širem gradskom području postoji velik broj vrtova odgojno-obrazovnih institucija s različitim biljnim vrstama. Ističu se utilitarne vrste, koje nisu bile u tolikoj mjeri očekivane za urbano područje. Zabilježene su sljedeće porodice s povrtnim vrstama: Aliaceae, Apiaceae, Asteraceae, Brassicaceae, Chenopodiaceae, Cucurbitaceae, Fabaceae, Solanaceae, te vrsta Zea mays koja se često spominje kao tradicijski bitna vrsta. Također je zabilježena raznovrsnost začinskog bilja. Voćke se pojavljuju u najmanjoj mjeri. Trešnja, Prunus avium, spominje se kao najčešća voćna vrsta, a tu su još i druge vrste roda Rosaceae, te orah, Juglans regia. To potvrđuje i istraživanje Horvatić (2018.) na području grada Zaprešića gdje se u vrtovima predškolskih i školskih institucija također mogu naći slične utilitarne vrste. Prema Božurić (2018.) istraživane škole na području Turopolja najviše su usmjerene na ukrasne vrste. Povrtne kulture se uzgajaju najmanje, točnije u dvije od ukupno 13 škola. Voćke su zastupljene u svega četiri škole. Od ukrasnih vrsta to su najčešće karanfili, maćuhice, ruže, pelargonije, potočnice, hortenzije. Uspoređujući takve rezultate s rezultatima uočenim na području OŠ Rugvica, zaključuje se da škole u urbanom području više naginju ka utilitarnim vrstama nego što je slučaj u ruralnom kraju.

Prijedlog vrsta i vrtlarskih aktivnosti

Adekvatno uređeno školsko dvorište postaje svojevrsna učionica, mjesto učenja i odgoja. Iz tog razloga je vrlo važno da se planiranje i projektiranje školskog vrta odradi na visokom nivou. 
Vesna Židovec i sur.: Odabir biljnih vrsta za školski vrt i plan vrtlarskih aktivnosti u OŠ Rugvica

OŠ Rugvica raspolaže velikom površinom koja je održavana i izuzetno atraktivna. Veći prostor otvara i više mogućnosti, posebice kad se radi o drveću i grmlju, te vrtno-tehničkim elementima (staze, sjenice, kamenjare, itd.) što je već uvršteno u školski okoliš. Kako u školskom dvorištu već postoji ukrasno drveće, grmlje, održavana živica, prijedlog vrsta se odnosi na sljedeće kategorije: povrtni vrt, voćni vrt, začinski i ljekoviti vrt, te tradicionalni cvjetnjak. Trstenjak (1883.) tvrdi da se školski vrt mora podjeliti u posebne odjele, što je dobar i pregledan koncept kojeg se valja držati. Međutim, kod Trstenjaka je na prvom mjestu učenje o uzgoju kako bi prinos bio što veći. $U$ ovom slučaju je prvenstveno riječ o uzgoju radi učenja i stjecanju spoznaje o prirodi, te kvalitetnom suživotu $\mathrm{s}$ istom. Osim toga, prilikom odabira vrsta vodilo se računa o tradiciji posavskog kraja.

U Tablici 2. navedeno je nekoliko vrsta povrća koje nemaju prevelike uzgojne zahtjeve i učenici ih mogu uz pomoć mentora uspješno uzgojiti, a za berbu dozrijevaju uglavnom tijekom školske godine. Osim samih plodova koje povrtna gredica daje, ostaje prostora za učenje o morfologiji biljaka, o različitim zahtjevima pojedine vrste, te njihovom međusobnom odnosu. Ako se lijepo oblikuje, povrtni vrt može biti i vrlo dekorativan.

Tablica 2. Prijedlog povrtnih vrsta za školsku gredicu

Table 2 Vegetable species for school bed proposal

\begin{tabular}{|l|c|c|c|}
\hline \multicolumn{4}{|c|}{ PRIJEDLOG VRSTA ZA POVRTNI VRT/ PROPOSAL OF VEGETABLE SPECIES } \\
\hline SPECIES & $\begin{array}{c}\text { NAZIV/ } \\
\text { NAME }\end{array}$ & $\begin{array}{c}\text { VRIJEME SJETVE/SADNJE } \\
\text { SOWING/PLANTING TIME }\end{array}$ & BERBA/HARVEST \\
\hline Allium cepa L. & Luk & III. & IX. \\
\hline Allium fistulosum L. & Mladi luk & IX., X. & III., IV. \\
\hline Allium sativum L. & Češnjak & X. & VI. \\
\hline Daucus carota L. & Mrkva & III.-VII. & VI.-IX. \\
\hline Lactuca sativa L. & Salata & II.-VI. & IV.-VII. \\
\hline Phaseolus vulgaris L. & Grah & IV-VII. & VI.-VIII. \\
\hline Pisum sativum L. & Grašak & II.-IV. & IV.-VII. V. \\
\hline Raphanus sativus L. & Rotkvica & II., III. & VI.-IX. \\
\hline $\begin{array}{l}\text { Solanum lycopersicum } \text { L. } \\
\text { var. cerasiforme } \\
\text { (Dunal) A. Gray }\end{array}$ & $\begin{array}{c}\text { Cherry } \\
\text { rajčica }\end{array}$ & II.-IV. & X.-III. \\
\hline Valerianella locusta L. & Matovilac & VIII.-X. & \\
\hline
\end{tabular}


Vesna Židovec i sur.: Odabir biljnih vrsta za školski vrt i plan vrtlarskih aktivnosti u OŠ Rugvica

Tablica 3. sadrži prijedlog vrsta za voćni vrt s namjerom da se isti oplemeni tradicionalnim voćkama. Osim tradicije bitan aspekt je u koje doba pojedina vrsta dozrijeva. Naravno, poželjno je koristiti vrste koje daju plod u vremenu trajanja školske godine. Kirin (2016.) navodi sorte voćaka koje su bile zastupljene na području Rugvice. Tako se ističe šljiva bistrica, plavoljubičastog ploda, za koju je idealno vrijeme berbe oko Male Gospe (8. rujna). Šljive su se sušile, kuhao se kompot, radio pekmez i pekla rakija. Sorata jabuka je bilo mnogo, a po okusu je bila najbolja koženika, koja je i zadnja dozrijevala.

Tablica 3. Prijedlog voćnih vrsta za školski vrt

Table 3 Fruit species for school garden proposal

\begin{tabular}{|l|c|c|}
\hline \multicolumn{2}{|c|}{ PRIJEDLOG VRSTA ZA VOĆNI VRT/PROPOSAL OF FRUIT SPECIES } \\
SPECIES & $\begin{array}{c}\text { NAZIV/ } \\
\text { NAME }\end{array}$ & $\begin{array}{c}\text { VRIJEME DOZRIJEVANJA } \\
\text { /HARVESTING TIME }\end{array}$ \\
\hline Corylus avellana L. & Lijeska & VIII.-X. \\
\hline Cydonia oblonga Mill. & Dunja & IX.,X. \\
\hline Fragaria L. & Jagoda & V.,VI. \\
\hline Malus x domestica Borkh. & Jabuka & IX.,X. \\
\hline Prunus avium L. & Trešnja & VI. \\
\hline Prunus domestica L. & Šljiva & VIII.-X. \\
\hline Pyrus communis L. & Kruška & IX.,X. \\
\hline Ribes rubrum L. & Crveni ribiz & VI. \\
\hline Rubus idaeus L. & Malina & VI. \\
\hline
\end{tabular}

Grudiček-Kozjak (2005.) navodi još nekoliko voćnih vrsta prikladnih za školski vrt, a to su: Juglans regia L., Cornus mas L., Crataegus monogyna Jacq., Crataegus oxyacantha L., Sambucus nigra L. temeljem provedenog istraživanja može se primijetiti da su navedene vrste bile nekad prisutne na području Rugvice i rugvičkog školskog vrta, a pojedine se mogu pronaći i danas. Korištenje tradicionalnih i autohtonih vrsta je logičan izbor i s aspketa uspješnosti uzgoja jer im uvjeti u posavskom kraju provjereno odgovaraju.

Začinsko i ljekovito bilje je skupina biljaka koje sadrže biološki aktivne tvari s praktičnom primjenom u prehrambenoj, farmaceutskoj i kozmetičkoj industriji. Za učenike je takvo bilje zanimljivo zbog aromatičnosti i jednostavnog načina korištenja. Uzgoj začinskog bilja može se prakticirati na otvorenom, ali i u učionici ili na prozorskoj dasci. U Tablici 4. su predložene začinske i ljekovite biljke za aromatičnu gredicu. 
Vesna Židovec i sur.: Odabir biljnih vrsta za školski vrt i plan vrtlarskih aktivnosti u OŠ Rugvica

Tablica 4. Prijedlog začinskih i ljekovitih vrsta za školsku gredicu

Table 4 Aromatic and medicinal species for school bed proposal

\begin{tabular}{|l|c|c|}
\hline \multicolumn{3}{|c|}{ PRIJEDLOG VRSTA ZA ZAČINSKI I LJEKOVITI VRT/ } \\
\hline \multicolumn{1}{|c|}{ PROPOSAL OF AROMATIC AND MEDICINAL SPECIES } \\
\hline Anethum graveolens L. & Kopar & NAJČEŠĆA UPOTREBA/COMMON USE \\
\hline Artemisia absinthium L. & Pelin & Čaj, proizvodnja alkoholnog pića, repelent \\
\hline Melissa officinalis L. & Matičnjak & Čaj, eterično ulje, začin, repelent \\
\hline Mentha x piperita L. & Paprena metvica & Čaj, eterično ulje, začin \\
\hline Ocimum basilicum L. & Bosiljak & Eterično ulje, začin \\
\hline Origanum majorana L & Mažuran & Čaj, eterično ulje, začin \\
\hline Origanum vulgare L. & Origano & Čaj, eterično ulje, začin \\
\hline Pimpinella anisum L. & Anis & Čaj, eterično ulje, začin \\
\hline Rosmarinus officinalis L. & Ružmarin & Eterično ulje, začin, repelent \\
\hline Salvia officinalis L. & Kadulja & Čaj, eterično ulje, začin, repelent \\
\hline Thymus vulgaris L. & Timjan & Čaj, eterično ulje, začin \\
\hline
\end{tabular}

U školskom vrtu kojeg opisuje Trstenjak (1883.) prisutne su začinske vrste, tj. mirodijske biline. Siju se ili sade među povrćem ili uz rub gredica.

Jambrek (2017.) je zabilježila prisustvo različitih začinskih i aromatičnih biljaka u vrtovima odgojno-obrazovnih institucija na području Novog Zagreba. Izuzev vrsta navedenih u Tablici 4. determinirane su sljedeće vrste: Carum carvi, Petroselinum crispum, Verbena officinalis, Lavandula officinalis.

Prijedlog cvjetnih vrsta prikazan je u Tablici 5., a sastavljen je prvenstveno prema rezultatima intervjua. Među predloženim vrstama prevladavaju trajnice koje su jednostavnije za održavanje od jednogodišnjih ili dvogodišnjih vrsta. Iako je Calendula officinalis uvrštena među ukrasne vrste, bitno je obratiti pozornost i na utilitarnu svrhu te vrste. Tako i vrsta Chaenomeles japonica ima ukrasnu i utilitarnu funkciju. Ima zanimljiv i lijep cvat, a plodovi, koji dozrijevaju u kasnu jesen, se mogu upotrijebiti u pekmezima i kompotima.

Cvjetne vrste bi trebale biti zanimljivih oblika i boja, što ih čini upotrebljivim u sklopu nastave iz likovne kulture i različitih radionica edukativno-zabavnog karaktera. Trstenjak (1883.) kaže kako će 'cvijeće u djeci probuditi osjećaj za krasne oblike i boje, razblažiti srce i dušu'. 
Vesna Židovec i sur.: Odabir biljnih vrsta za školski vrt i plan vrtlarskih aktivnosti u OŠ Rugvica

Tablica 5. Prijedlog cvjetnih vrsta za školsku gredicu

Table 5 Flower speices for school bed proposal

\begin{tabular}{|c|c|c|c|}
\hline \multicolumn{4}{|c|}{$\begin{array}{l}\text { PRIJEDLOG VRSTA ZA TRADICIONALNI CVJETNJAK/ } \\
\text { PROPOSAL OF SPECIES FOR TRADITIONAL FLOWER BED }\end{array}$} \\
\hline $\begin{array}{l}\text { VRSTA/ } \\
\text { SPECIES }\end{array}$ & $\begin{array}{l}\text { NAZIV/ } \\
\text { NAME }\end{array}$ & $\begin{array}{l}\text { KATEGORIJA/ } \\
\text { CATEGORY }\end{array}$ & $\begin{array}{l}\text { VRIJEME CVJETANJA/ } \\
\text { /FLOWERING TIME }\end{array}$ \\
\hline Asclepias syriaca $\mathrm{L}$. & Cigansko perje & Višegodišnja vrsta & IX.,X. \\
\hline Begonia semperflorens $\mathrm{L}$. & Begonija & Višegodišnja vrsta & V.-X. \\
\hline Calendula officinalis $\mathrm{L}$. & Neven & Jednogodišnja vrsta & VI.-XI. \\
\hline Celosia plumosa L. & Pijetlova kresta & Jednogodišnja vrsta & VI.-X. \\
\hline $\begin{array}{l}\text { Chaenomeles japonica } \\
\text { (Thunb.) Lindl. Ex Spach }\end{array}$ & Japanska dunja & Grm & II.-IV. \\
\hline Crocus sativus L. & Šafran & Geofit & II.,III. \\
\hline $\begin{array}{l}\text { Dhalia variabilis (Wild.) } \\
\text { Desf. }\end{array}$ & Dalija & Višegodišnja vrsta & VII.-X. \\
\hline Dianthus caryophyllus L. & Karanfil & Višegodišnja vrsta & V.,VI. \\
\hline Dicentra spectabilis L. & Srdašca & Višegodišnja vrsta & VI.,V. \\
\hline Erysimum cheiri (L.) Crantz & Šeboj & Višegodišnja vrsta & III.,IV. \\
\hline Hyacinthus orientalis L. & Zumbul & Geofit & III.,IV. \\
\hline $\begin{array}{l}\text { Hydrangea macrophylla } \\
\text { (Thunb.) Ser. }\end{array}$ & Hortenzija & Grm & V.-IX. \\
\hline Iris germanica $\mathrm{L}$ & Perunika & Geofit & V.-VII. \\
\hline Juncus articulatus L. & Sit & Višegodišnja vrsta & - \\
\hline Mirabilis jalapa $\mathrm{L}$. & Noćna dama & Višegodišnja vrsta & V.-IX. \\
\hline Narcissus poeticus L. & Narcis & Geofit & III.,IV. \\
\hline Paeonia officinalis L. & Božur & Višegodišnja vrsta & V.,VI. \\
\hline Pelargonium zonale L. & Pelargonija & Višegodišnja vrsta & IV.-XI. \\
\hline Portulaca grandiflora Hooker & Prkos & Jednogodišnja vrsta & VI.-X. \\
\hline Rosa spp. & Ruža & Grm & V.-X. \\
\hline Sempervivum tectorum $\mathrm{L}$. & Čuvarkuća & $\begin{array}{l}\text { Višegodišnja vrsta, } \\
\text { sukulent }\end{array}$ & VII.,VIII. \\
\hline Tagetes erecta $\mathrm{L}$. & Kadifica & Jednogodišnja vrsta & V.-X. \\
\hline Viola odorata $\mathrm{L}$. & Ljubičica & Trajnica & III.,IV. \\
\hline Viola $\times$ wittrockiana Gams. & Maćuhica & Dvogodišnja vrsta & III.-V. \\
\hline Zinnia elegans Jacq. & Cinija & Jednogodišnja vrsta & VI.-X. \\
\hline
\end{tabular}


Prema Kirin (2016.) vrt u rugvičkom kraju nije bio rezerviran samo za povrće. U njemu se sadilo i cvijeće. U svibnju su to bili klinčeki (kranfili), trojačke (božuri), srčeka (srdašca) i turski karanfili. Uz kuću su cvali jorgovani, a na prozorskim daskama su bile belagonije (pelargonije) i asparagus. Kirin (2016.) također navodi kako su 50-ih godina žene odlazile na more i sa sobom donosile mediteranske vrste poput ružmarina i oleandra.

Za razliku od predloženog, Pirić (2016.) je u vrtovima odgojno-obrazovnih institucija u Sesvetama utvrdila najčešću prisutnost jednogodišnjih i dvogodišnjih vrsta. Bellis perennis je najzastupljenija vrsta, prisutna u gotovo svakom vrtu, kao i Viola $\times$ wittrockiana. Jambrek (2017.) je na području Novog Zagreba utvrdila da su najprisutnije trajnice i geofiti. Rosa spp. je zabilježena u gotovo svakom vrtu, a za ružom slijede: Iris germanica, Viola odorata, Taraxacum officinalis. Istraživanje koje je provela Horvatić (2018.) također je pokazalo veću zastupljenost trajnica i geofita u vrtovima predškolskih i školskih institucija na području grada Zaprešića. Najzastupljenije vrste su: Muscari armeniacum, Narcissus spp., Lilium regale, Stachys byzantina, Pelargonium grandiflorum i Hemerocalis fulva.

Aktivnosti kojima se djeca mogu baviti u sklopu nastave trebaju biti edukativnog karaktera, ali istodobno dovoljno zanimljiva i zabavna. Poželjno je s radionicama početi već u nižim razredima osnovne škole kako bi im vrtne aktivnosti od samih početaka bile bliske i prešle u naviku. Radionice je moguće podijeliti tematski po godišnjim dobima. Prijedlog radionica je naveden u tablici 6., a podijeljen je prema godišnjim dobima na jesenske, zimske, proljetne i ljetne radionice. $U$ tablicama su navedeni nazivi radionica, osnovni materijali koji su potrebni za izvedbu radionica i kratki opis. Kao što se iz tablice može primijetiti, naglasak je na upotrebi prirodnih materijala, ponovnom korištenju različitih materijala (recikliranje), osnovni materijal koji se koristi u svakoj od radionica moguće je pronaći u školskom vrtu ili okolišu škole, radionicama se učenicima skreće pozornost na biološku raznolikost kroz brigu o različitih biljnim (uzgoj različitih vrsta biljaka, jesensko slikarstvo, jesensko modeliranje, izrada slika od sjemenki, izrada herbarija, ...), ali i životinjskim vrtama (kukci, ptice), održivost (skupljanje sjemena, kompostiranje), očuvanje lokalnog identiteta (uzgoj zavičajnih vrsta, izrada tradicijskih igračaka), očuvanje tradicijskih običaja i vrijednosti (adventske i uskršnje radionice). 
Tablica 6. Prijedlog radionica

Table 6 Workshops proposal

\begin{tabular}{|c|c|c|}
\hline \multicolumn{3}{|r|}{ JESEN/AUTUMN } \\
\hline $\begin{array}{l}\text { NAZIV } \\
\text { RADIONICE/ } \\
\text { WORKSHOPS' } \\
\text { NAME }\end{array}$ & $\begin{array}{l}\text { MATERIJAL/ } \\
\text { MATERIAL }\end{array}$ & $\begin{array}{c}\text { KRATKI OPIS/ } \\
\text { SHORT DESCRIPTION }\end{array}$ \\
\hline \multirow[b]{2}{*}{ Školska oaza } & \multirow{2}{*}{$\begin{array}{l}\text { Sjeme, presadnice, } \\
\text { gomolji i lukovice. } \\
\text { Grablje, lopatica, } \\
\text { vrtne škare, } \\
\text { posuda za vodu }\end{array}$} & $\begin{array}{l}\text { Gredice je potrebno pripremiti za sjetvu ili sadnju. Nakon } \\
\text { pripreme djeca siju ili sade odabrano voće, povrće, začinsko } \\
\text { bilje i ukrasne vrste. Uči se o životnom ciklusu biljke i } \\
\text { načinima kako je uspješno njegovati. }\end{array}$ \\
\hline & & $\begin{array}{l}\text { Lukovice i gomolji su specifičnog izgleda. Presjekom lukovice } \\
\text { i gomolja učenici će se upoznati sa zanimljivom funkcijom koju } \\
\text { imaju u ishrani same biljke i njezinom razvoju. Prije prvog } \\
\text { mraza lukovice se sade na gredice kako bi prve najavile } \\
\text { proljeće. Najčešće se od lukovica sade tulipani, zumbuli, } \\
\text { narcise, a od gomolja šafrani, frezije. }\end{array}$ \\
\hline $\begin{array}{l}\text { Škola } \\
\text { kompostiranja }\end{array}$ & $\begin{array}{l}\text { Drvene } \\
\text { palete/daske, } \\
\text { čavli }\end{array}$ & $\begin{array}{l}\text { Nakon što je odabrano odgovarajuće mjesto, izrađuje se } \\
\text { komposter od drvenih paleta. Smanjuje se količina otpada i } \\
\text { poboljšava se kvaliteta tla. Učenici uče o važnosti komposta, } \\
\text { načinu izrade i korištenja. }\end{array}$ \\
\hline $\begin{array}{l}\text { Prikupljanje } \\
\text { sjemena }\end{array}$ & $\begin{array}{l}\text { Cjedilo ili gaza, } \\
\text { papir, papirnata } \\
\text { omotnica ili } \\
\text { staklene posude za } \\
\text { čuvanje sjemena }\end{array}$ & $\begin{array}{l}\text { Kada su plodovi zreli, zrelo je i sjeme. Ono se prikuplja, ispire i } \\
\text { suši. Učenici mogu izraditi papirnate omotnice u koje će pohraniti } \\
\text { prikupljeno sjeme. Na omotnicu se piše ime vrste i datum kad je } \\
\text { sjeme skupljeno. Čuvati se može i u staklenim posudama. } \\
\text { Poželjno je da bude pohranjeno na hladnije i suho mjesto. }\end{array}$ \\
\hline \multirow{4}{*}{$\begin{array}{l}\text { Jesensko } \\
\text { slikarstvo }\end{array}$} & \multirow{4}{*}{$\begin{array}{c}\text { Materijali } \\
\text { iz prirode } \\
\text { (lišće, grančice, } \\
\text { plodovi, kora } \\
\text { drveta, cvjetovi, } \\
\text { stapke, mahovina, } \\
\text { kamenčići, sjeme), } \\
\text { likovna oprema } \\
\text { (papir, olovka, } \\
\text { vodene bojice, } \\
\text { tempere, ljepilo, } \\
\text { škare) }\end{array}$} & $\begin{array}{l}\text { Sve što se može prikupiti u školskom okruženju ili na putu do } \\
\text { kuće, učenicima može poslužiti kao sredstvo likovnog } \\
\text { izražavanja. } \\
\text { Kolaž od listova u jesenskim bojama će rezultirati zanimljivim } \\
\text { radom sa lijepim bojama. Lišće skupljeno u prirodi se lijepi na } \\
\text { papir. Stvara se kompozicija koja se može obogatiti i drugim } \\
\text { skupljenim materijalom (žir, grančice, kora od drveta itd.). } \\
\text { Stvara se 3D efekt. }\end{array}$ \\
\hline & & $\begin{array}{l}\text { Preslikavanje listova i cvjetova na papir je zanimljiva aktivnost } \\
\text { s još zanimljivijim rezultatima. Materijal se obilato boja } \\
\text { temperom ili vodenim bojicama, zatim se prislanja na papir } \\
\text { gdje ostaje zanimljiv otisak, nešto poput pečata. }\end{array}$ \\
\hline & & $\begin{array}{l}\text { Izrada mozaika od sjemena. Sjeme može biti zanimljivih oblika } \\
\text { i boja. Ljepljenjem na papir postižu se zanimljivi oblici i slike. } \\
\text { Nakon što učenici skupe sjeme, dio se odloži za kasniju sjetvu } \\
\text { ili poklone, a dio se proučava i koristi kao likovni materijal. }\end{array}$ \\
\hline & & $\begin{array}{l}\text { Tehnika frotaž je slikarska tehnika trljanja grafita po tankom } \\
\text { papiru ispod kojeg je položen predmet. Učenici pod papir mogu } \\
\text { staviti list ili cvijet. Rezultat će biti efektan i zanimljiv jer se na } \\
\text { papiru na taj način ocrtaju i žilice na listu. }\end{array}$ \\
\hline
\end{tabular}




\begin{tabular}{|c|c|c|}
\hline \multirow{3}{*}{$\begin{array}{l}\text { Jesensko } \\
\text { modelarstvo }\end{array}$} & \multirow{3}{*}{$\begin{array}{l}\text { Materijali iz } \\
\text { prirode (lišće, } \\
\text { grančice, plodovi, } \\
\text { kora drveta, } \\
\text { cvjetovi, stapke, } \\
\text { mahovina,kamenči } \\
\text { ći,sjeme), likovna } \\
\text { oprema (papir, } \\
\text { olovka, vodene } \\
\text { bojice, tempere, } \\
\text { ljepilo, konop) }\end{array}$} & $\begin{array}{l}\text { Izrada gnijezda od grančica i šiba. Lako savitljive grane su } \\
\text { dobar materijal za gnijezdo. Ono se može oplemeniti raznim } \\
\text { predmetima poput kamenčića, grančica, može se ukrasiti } \\
\text { mahovinom i lišćem. }\end{array}$ \\
\hline & & $\begin{array}{l}\text { Okvir za slike od grana je jednostavan način kojim slika od } \\
\text { biljnog materijala može postati još zanimljivija. Četiri grančice } \\
\text { se povežu konopom ili ljepilom i pričvrsti se slika. Okvir se } \\
\text { može oplemeniti raznim biljnim materijalom. }\end{array}$ \\
\hline & & $\begin{array}{l}\text { Skulpture i predmeti od biljnog materijala je tehnika koju su } \\
\text { nekad učenici dobro poznavali i na taj način su sami izrađivali } \\
\text { igračke. Za tako nešto je potrebna vještina, ali kad se usavrši } \\
\text { samo treba pustiti mašti da vodi. Izrada lutki, nakita, skulptura } \\
\text { od lišća i daščica, smotuljci od kore drveta, izrada odjeće za } \\
\text { lutke (kukuruzovina). }\end{array}$ \\
\hline $\begin{array}{l}\text { Priprema } \\
\text { pekmeza }\end{array}$ & $\begin{array}{l}\text { Sezonsko voće } \\
\text { (šljive, bobičasto } \\
\text { voće poput maline } \\
\text { i kupine, šipak, } \\
\text { bazga), lonac, } \\
\text { voda, šećer, začini, } \\
\text { limun, staklenke }\end{array}$ & $\begin{array}{l}\text { Kako bi pripremili pekmez potrebno je odabrano voće i šećer } \\
\text { kuhati do željene gustoće. Okus se može oplemeniti s malo } \\
\text { limuna i drugih začina poput cimeta, klinčića, itd. Iako samo } \\
\text { kuhanje zahtjeva strpljenje, krajnji rezultat će biti } \\
\text { zadovoljavajući. Kako bi pekemz bio adekvatno pohranjen, } \\
\text { pripremaju se staklenke za koje učenici mogu izraditi } \\
\text { naljepnice na kojima će pisati koji je pekmez i kad je izrađen. } \\
\text { Učenici će sigurno sa zadovoljstvom konzumirati pekmez koji } \\
\text { su gotovo samostalno pripemili, a s lijepo dekoriranim } \\
\text { naljepnicama, teglica domaćeg pekemza je odličan poklon za } \\
\text { skorašnje zimske blagdane. }\end{array}$ \\
\hline \multicolumn{3}{|r|}{ ZIMA/WINTER } \\
\hline $\begin{array}{l}\text { NAZIV } \\
\text { RADIONICE/ } \\
\text { WORKSHOPS' } \\
\text { NAME }\end{array}$ & $\begin{array}{l}\text { MATERIJAL/ } \\
\text { MATERIAL }\end{array}$ & $\begin{array}{c}\text { KRATKI OPIS/ } \\
\text { SHORT DESCRIPTION }\end{array}$ \\
\hline $\begin{array}{l}\text { Kućica } \\
\text { za ptice }\end{array}$ & $\begin{array}{l}\text { Daska, čavli, } \\
\text { ljepilo, plastične } \\
\text { boce, tetrapak, } \\
\text { hrana za ptice } \\
\text { (sjemenke, } \\
\text { voće, itd.) }\end{array}$ & $\begin{array}{l}\text { Kućica može biti izrađena od veće boce ili tetrapaka na kojima } \\
\text { se naprave otvori poput vrata i prozora. Također, kućica može } \\
\text { biti od drvenih dasaka spojenih ljepilom ili čavlima u oblik } \\
\text { trokuta. Kućice se dekoriraju prema željama učenika i ispune } \\
\text { mješavinom sjemenki. Učenici se povezuju s prirodom, a usput } \\
\text { uče o važnosti ptica u održavanju bioraznolikosti. }\end{array}$ \\
\hline $\begin{array}{l}\text { Hotel } \\
\text { za kukce }\end{array}$ & $\begin{array}{l}\text { Drvena } \\
\text { konstrukcija, } \\
\text { cjepanice, } \\
\text { cigle, grančice, } \\
\text { suho lišće, } \\
\text { češeri, slama, } \\
\text { kora drveta i sl. }\end{array}$ & $\begin{array}{l}\text { Kukci su saveznici dobrog vrta. Suzbijaju brojne nametnike, } \\
\text { važni su za oprašivanje biljaka, rahle tlo kopajući tunele. Važan } \\
\text { su dio biološkog lanca i ekosustava u vrtu. Važno je da učenici } \\
\text { postanu svjesni uloge kukaca i da im, kao i pticama, pomognu } \\
\text { da prezime. Drvena konstrukcija se ispunjava raznim matrijalim } \\
\text { poput cjepanica s izdubljenim rupama, ciglama, grančicama, } \\
\text { češerima, lišćem i drugim organiskim materijalima koji } \\
\text { kukcima pružaju dom za zimskih dana. }\end{array}$ \\
\hline
\end{tabular}




\begin{tabular}{|c|c|c|}
\hline $\begin{array}{l}\text { Adventske } \\
\text { radosti }\end{array}$ & $\begin{array}{l}\text { Šibe, grane, } \\
\text { češeri, crnogorica, } \\
\text { plodovi, žica, } \\
\text { ljepilo, silikon, } \\
\text { stiropor, staklenke, } \\
\text { karton, mješavina } \\
\text { sjemenki }\end{array}$ & $\begin{array}{l}\text { Adventski ukrasi mogu biti unikatni i izrađeni od materijala } \\
\text { nađenih u prirodi. Primjerice šibe breze skupljne u snop su lako } \\
\text { savitljive i mogu se oblikovati. Saviju se u kružni oblik i na par } \\
\text { mjesta povežu žicom kako se ne bi razmotale. Nakon što je } \\
\text { osnovna konstrukcija vijenaca izrađena, detalji ovise o željama } \\
\text { učenika i prikupljenom materijalu. Umetanjem grančica } \\
\text { crnogorice u vijenac dobije se, osim vizualnog dojma, i miris } \\
\text { blagdana. Razmrvljenji stiropor ima ulogu snijega kojim se } \\
\text { mogu obložiti kuglice, posude za cvijeće, stare staklenke mogu } \\
\text { postati atraktivni svijećnjaci. Ukrasi za bor su jednostavni za } \\
\text { izraditi od kartona koji se uzreže u raznim oblicima, umoči u } \\
\text { ljepilo te uvalja u mješavinu sjmenki. U tu svrhu može poslužiti } \\
\text { i prikupljeno sjeme, posebice ono koje djeluje dekorativno } \\
\text { (npr.sjeme nevena). }\end{array}$ \\
\hline $\begin{array}{l}\text { Multifunkcionalni } \\
\text { balon }\end{array}$ & $\begin{array}{l}\text { Balon, ljepilo, } \\
\text { prozirni papir, } \\
\text { lišće, žica }\end{array}$ & $\begin{array}{l}\text { Uz pomoć balona mogu se izraditi zanimljivi fenjeri s biljnim } \\
\text { motivom. Balon se premaže ljepilom i zaljepe se komadi } \\
\text { papira. Na taj sloj se stavi list ili cvijet. Zatim se prekrije } \\
\text { dodatnim slojem papira kako bi sve ostalo na mjestu. Nakon } \\
\text { tog koraka potrebno je strpljenje kako bi se materijal dobro } \\
\text { osušio. Kada je sve suho, vrh balona gdje je čvor se lako } \\
\text { odreže, ostatak balona se izvuče. Pomoću žice ili konopa izrade } \\
\text { se ručke pomoću kojih se fener može objesiti u prostoru. Uz } \\
\text { minimalno materijala izrade se zanimljivi fenjeri s biljnim } \\
\text { motivom. }\end{array}$ \\
\hline $\begin{array}{l}\text { Vrtni } \\
\text { putokazi }\end{array}$ & $\begin{array}{l}\text { Drvene dašćice, } \\
\text { čavli, vodootporni } \\
\text { marker, žlica, } \\
\text { ljepilo, katalog } \\
\text { biljaka, ljepilo, } \\
\text { marker }\end{array}$ & $\begin{array}{l}\text { Kako bi snalaženje po vrtu bilo olakšano i edukativno,izrađuju } \\
\text { se oznake s imenom vrste koji označava mjesto iste u vrtu ili na } \\
\text { gredici. Klasični oblik bi bio spajanje dvije daščice čavlom i } \\
\text { ispisivanje imena vrste vodootpornim markerom. Možda malo } \\
\text { neobičnija varijanta je pomoću žlice, fotografije i imena vrste. } \\
\text { Na žlicu se zaljepi fotografija vrste i ispiše se ime. Fotografije } \\
\text { se mogu pronaći na raznim izvorima (internet, katalog, časopisi, } \\
\text { novine. }\end{array}$ \\
\hline $\begin{array}{l}\text { Cvjetni } \\
\text { prosinac }\end{array}$ & $\begin{array}{c}\text { grana voćke } \\
\text { s pupovima, } \\
\text { vrtne škare, vaza }\end{array}$ & $\begin{array}{l}\text { Zima se može prevariti i u prosincu oplemeniti prostor } \\
\text { rascvjetalom granom voćke. Početkom prosinca odreže se } \\
\text { grančica voćke, stavi u vodu i na toplo. Kad su joj osigurani } \\
\text { adekvatni uvijeti, grana će procvasti do Božića. Voćke koje } \\
\text { mogu poslužiti su bazga, breskva, jabuka, šljiva, trešnja, } \\
\text { kruška, ali i dvilji kesten i forzicija. }\end{array}$ \\
\hline
\end{tabular}


Vesna Židovec i sur.: Odabir biljnih vrsta za školski vrt i plan vrtlarskih aktivnosti u OŠ Rugvica

\begin{tabular}{|c|c|c|}
\hline \multicolumn{3}{|r|}{ PROLJEĆE/SPRING } \\
\hline $\begin{array}{c}\text { NAZIV } \\
\text { RADIONICE/ } \\
\text { WORKSHOPS' } \\
\text { NAME }\end{array}$ & $\begin{array}{l}\text { MATERIJAL/ } \\
\text { MATERIAL }\end{array}$ & $\begin{array}{c}\text { KRATKI OPIS/ } \\
\text { SHORT DESCRIPTION }\end{array}$ \\
\hline Izrada herbarija & $\begin{array}{l}\text { Dvije kartonske } \\
\text { plohe, novinski } \\
\text { papir, vrtne škare, } \\
\text { lopatica, teške } \\
\text { knjige/kutije, } \\
\text { A4 papir, } \\
\text { ljepljiva traka, } \\
\text { cedulja s } \\
\text { detaljima, } \\
\text { prozirne A4 } \\
\text { perofirane } \\
\text { košuljice, } \\
\text { fascikla } \\
\end{array}$ & $\begin{array}{l}\text { Izrada herbarija se može podjeliti na tri jednostavna koraka: } \\
\text { skupljanje biljaka, sušenje i postavljanje u herbarij. Prilikom } \\
\text { skupljanja biljaka potrebno je uzeti sa sobom adekvatno } \\
\text { "spremište za biljke", na primjer dvije plohe kartona i novinski } \\
\text { papir u koji će se umetati biljke. Ako se biljka ne može skupiti } \\
\text { golom rukom, vrtne škare ili lopatica (za podzemne djelove) će } \\
\text { pomoći. Zatim kreće sušenje biljaka. Taj korak je izuzetno } \\
\text { bitan. Biljke se uredno stavljaju u novinski papir. Ako su biljke } \\
\text { vlažne, više puta se mijenja papir. Za prešanje je najbolje } \\
\text { koristiti teške knjige ili kutije. Kada su se dobro posušile, slijedi } \\
\text { postavljanje u herbarij. Najbolje je lijepiti biljku na A4 papir. } \\
\text { Izrađuje se papirnata cedulja s imenom biljke, datumom i } \\
\text { mjestom prikupljanja, te ime prikupljača. }\end{array}$ \\
\hline \multirow[t]{2}{*}{ Viseći vrt } & \multirow[t]{2}{*}{$\begin{array}{l}\text { Plastične boce, } \\
\text { staklene boce, } \\
\text { kutije od } \\
\text { sladoleda, } \\
\text { konop, silikon, } \\
\text { supstrat, sjeme }\end{array}$} & $\begin{array}{l}\text { Učenici su već naučili kako od plastične boce ili tetrapaka } \\
\text { izraditi kućicu za ptice. Takvoj vještini može se pridružiti } \\
\text { izrada posuda za biljke od plastičnih boca. Boce se prerežu na } \\
\text { pola, bočno se probuše rupice kroz koje se provuče konop i } \\
\text { izrađena je posuda za biljke koje želite. Na duži konop se može } \\
\text { povezati više posuda, jedna ispod druge, i zatim objesiti na } \\
\text { prozor ili adekvatan vanjski prostor. Osim presjeka boce na } \\
\text { polovici, posuda može biti i čitava boca koja se polegne } \\
\text { horizontalno i izrezbari se otvor kroz koji će se boca napunit } \\
\text { supstratom i željenim sjemenom ili presadnicom. Isti je princip } \\
\text { sa kutijom za sladoled, samo što je ta varijanta nešto olakšana } \\
\text { jer se ne treba ručno izrađivati otvor. Ono što se nikako ne } \\
\text { smije zaboraviti jest rupica na dnu posude kako bi voda mogla } \\
\text { otjecati. Kada je odrađen tehnički dio, nastupa umjetnički. } \\
\text { Učenici uređuju posude prema svojim željama. }\end{array}$ \\
\hline & & $\begin{array}{l}\text { Staklene boce se također mogu iskoristiti više puta. Iako ne u } \\
\text { svrhu visećeg vrta, svakako je u svrhu reciklaže. Proljetne } \\
\text { radionice na takvu temu su posebice prikladne uzimajući u } \\
\text { obzir da se } 22 \text {. travnja obilježava Dan planeta Zemlje. Tako uz } \\
\text { malo mašte, staklena boca postaje lijepa vaza za cvijeće. Uz } \\
\text { pomoć silikona ili ljepila boce se mogu obući u konop. Mogu se } \\
\text { oblijepiti korom drveta, grančicama i sličnim materijalima. }\end{array}$ \\
\hline Ručni rad & $\begin{array}{c}\text { Sit } \\
\text { (Juncus } \\
\text { artuculatus) }\end{array}$ & $\begin{array}{l}\text { Radionica "Ručni rad" bi prvenstveno trebala biti usmjerena na } \\
\text { učenje vještina kojima su djeca nekad jako dobro vladala. Izrada } \\
\text { malog namještaja i drugih predmeta od biljke čvrste strukture } \\
\text { poput sita, djeci na području Rugvice je nekad bila svakodnevna } \\
\text { igra. Danas se djeca igraju na druge načine. Osim očuvanja } \\
\text { tradicije, ovakva vještina je poželjna. Učenici se uče pletenju i to } \\
\text { s neobičnim materijalima, ujedno upoznaju tradiciju svog kraja. }\end{array}$ \\
\hline
\end{tabular}




\begin{tabular}{|c|c|c|}
\hline Prirodne pisanice & $\begin{array}{c}\text { Jaja, ocat, } \\
\text { najlonke ili gaza, } \\
\text { prirodne boje } \\
\text { od ljuske luka, } \\
\text { cikle, crveni } \\
\text { kupus, bazga, } \\
\text { crno grožđe, } \\
\text { kopriva, } \\
\text { čaj od kamilice, } \\
\text { list peršina, } \\
\text { konac }\end{array}$ & $\begin{array}{l}\text { Radionica koja je vezana uz uskršnju dekoraciju. Kako bi ostali } \\
\text { dosljedni ekologiji i izbjegli bojanje jaja sa štetnim umjetnim } \\
\text { bojama, kroz zabavnu radionicu učenici će naučiti kako su se jaja } \\
\text { bojala nekad i to prirodnim bojama. Jaje kuhano omotano u koru } \\
\text { od luka dobije smečkasto-narančastu boju koja daje pisanicama } \\
\text { lagano rustikalan izgled. Plavu boju će dobiti ako se jaja kuhaju s } \\
\text { crvenim kupusom ili bobicama bazge. Kopriva daje zelenu boju, } \\
\text { a čaj od kamilice blijedo žutu. Crvena boja dobije se od cikle, a } \\
\text { ljubičasta kuhanjem u soku od crnog grožđa. Ne smije se } \\
\text { zaboraviti ocat za fiksiranje boje. Naravno to su samo neki od } \\
\text { prijedloga, ali u ovom slučaju može se eksperimentirati. Kako bi } \\
\text { pisanice dobile zanimljiv uzorak, na ljusku se prislone listići, } \\
\text { konac u raznim oblicima i slično, te se pričvrsti uz pomoć gaze ili } \\
\text { najlonke. Zanimljiv, ekološki prihvatljiv, tradicionalan način } \\
\text { bojanja koji nema negativan utjecaj na zdravlje. }\end{array}$ \\
\hline $\begin{array}{l}\text { Dobar susjed - } \\
\text { loš susjed }\end{array}$ & $\begin{array}{l}\text { Luk i grašak/ } \\
\text { luk i kopar }\end{array}$ & $\begin{array}{l}\text { Jedna od zanimljivosti kod biljaka je da se ne vole sve vrste. } \\
\text { Učenici se primjerom uče kako sve biljke ne funkcioniraju u } \\
\text { blizini. Na izdvojenoj gredici uzgaja se luk i grašak, odnosno luk } \\
\text { i kopar. Luk i grašak nisu idealni susjedi, dok se kopar i luk dobro } \\
\text { slažu. Učenici vode bilješke, zapažaju kakve se promjene } \\
\text { događaju i u kakvom su stanju biljke. Na taj način će se upoznati } \\
\text { s pojmom alelopatije, kemijske interakcije među biljakama. }\end{array}$ \\
\hline Igra povezivanja & $\begin{array}{l}\text { Sjeme, } \\
\text { razvijena biljka }\end{array}$ & $\begin{array}{l}\text { Učenici su upoznati sa izgledom sjemena i njihovom ulogom. } \\
\text { Naravno, teško je za očekivati da će povezati sve vrste sjemena } \\
\text { s pripadajućom biljkom, ali pomoću igre će svakako zapamtiti } \\
\text { koju vrstu više. Na jedan papirić se zalijepi sjeme, a na drugi } \\
\text { biljka (ili slika biljke). Učenici izvlače karticu sa sjemenom, } \\
\text { koje moraju povezati s točnom biljkom. }\end{array}$ \\
\hline $\begin{array}{l}\text { Proizvodnja } \\
\text { presadnica }\end{array}$ & $\begin{array}{l}\text { Pakiranje za jaja, } \\
\text { role wc papira, } \\
\text { prozirne plastične } \\
\text { kutije za kolače s } \\
\text { poklopcem, } \\
\text { supstrat, sjeme }\end{array}$ & $\begin{array}{l}\text { Kako bi povrće dospjelo ranije, potencijalo imalo bolji prinos, } \\
\text { proizvde se presadnice. Plastična posuda s poklopcem je zgodna } \\
\text { jer djeluje kao mini plastenik, no role wc papira ili kutije od jaja } \\
\text { su biorazgradive i zato prihvatljivije. Supstratom se napune } \\
\text { posude, ubaci se sjeme i prekrije slojem supstrata. Preporučljivo } \\
\text { je dodati humusa koji se dobio kompostiranjem. Vrste koje su } \\
\text { dobar izbor za uzgoj iz prsadnica su: rajčia, krastavac, paprika, } \\
\text { grašak. Za razvoj presadnice bitni su: toplina, svjetlost, voda. Ako } \\
\text { su svi uvjeti zadovoljeni vrlo brzo će se razviti mala biljčica koja } \\
\text { će ostatak života nastaviti na gredici. }\end{array}$ \\
\hline Prozirni sapun & $\begin{array}{c}\text { Glicerinska baza, } \\
\text { kalup (čašica od } \\
\text { jogurta), suhi } \\
\text { cvijet, plod ili list, } \\
\text { eterično ulje, } \\
\text { prijanjajuća folija }\end{array}$ & $\begin{array}{l}\text { Izrada sapuna nije zahtjevan proces i ne traži previše sastojaka. } \\
\text { Onaj s kojim se djeca, u tom obliku, ne susreću često je } \\
\text { glicerinska baza. Potrbeno je usitniti i rastopiti. Kada je masa } \\
\text { otopljena, prelije se u odgovarajući kalup. Dno čašice od } \\
\text { jogurta je idealan kalup. U otopljenu masu uroni se cvijet ili } \\
\text { list, te nekoliko kapi eteričnog ulja po izboru. Sapun je gotov } \\
\text { kad se masa potpuno stvrdne. Poželjno ga je umotati u } \\
\text { prijanjajuću foliju kako bi što duže održao miris i svježinu. }\end{array}$ \\
\hline
\end{tabular}




\begin{tabular}{|c|c|c|}
\hline $\begin{array}{l}\text { Školska ljekarna - } \\
\text { nevenovo ulje } \\
\text { i mast }\end{array}$ & $\begin{array}{c}\text { Suhi i svježi } \\
\text { cvijet nevena, } \\
\text { suncokretovo ulje, } \\
\text { staklena posuda } \\
\text { koja se može } \\
\text { hermetički } \\
\text { zatvoriti, gaza, } \\
\text { tamne posude, } \\
\text { svinjska mast, } \\
\text { vatrostalna posuda }\end{array}$ & $\begin{array}{l}\text { Nevenovo ulje i mast su izuzetno ljekoviti, a jednostavni za } \\
\text { napraviti. Na školskim gredicama bi svakako svoje mjesto } \\
\text { trebao imati neven čije se latice mogu koristiti u ljekovite svrhe. } \\
\text { Tako da bi dobili ulje, ubacimo suhe latice u staklenu posudu i } \\
\text { prelijemo suncokretovim uljem. Zatvorenu posudu treba } \\
\text { protresti nekoliko puta dnevno, a nakon tri tjedna procjediti, uz } \\
\text { pomoć gaze, u tamne posude. Cuvati na hladnom i tamnom } \\
\text { mjestu. Za nevenovu mast potrebno je u vatrostalnoj posudi } \\
\text { otopiti svinjsku mast, zatim dodati svježi cvijet nevena. Smjesu } \\
\text { prekriti i ostaviti } 24 \text { sata, uz povremeno mješanje. Po isteku } \\
\text { vremena, zagrijati smjesu i procjediti kroz gazu. Mast je } \\
\text { najbolje čuvati u staklenoj posudi. }\end{array}$ \\
\hline Travnata glava & $\begin{array}{l}\text { Najlonke, } \\
\text { sjemenke, } \\
\text { piljevina, gumica, } \\
\text { posuda s vodom }\end{array}$ & $\begin{array}{l}\text { Najlonke se odrežu na dužinu od oko } 30 \mathrm{~cm} \text {. S jedne strane se } \\
\text { sveže čvor, a s druge se stavi šaka sjemenki. Ostatak najlonke } \\
\text { se napuni piljevinom. Čvor se sveže na vrhu i gumicom se } \\
\text { oblikuje nos na sredini. Tako pripremljena glava se uroni u } \\
\text { posudu s vodom. Glava se odloži na tanjurić tako da sjemenke } \\
\text { budu na vrhu. Dok trava počne bujati, ima vremena za } \\
\text { uljepšavanje glave. Pomoću gumba postave se oči, usta i drugi } \\
\text { detalji po želji. Svaki dan je potrebno pošpricati glavu, a kad } \\
\text { trava krene rasti, može se oblikovati frizura. }\end{array}$ \\
\hline \multicolumn{3}{|r|}{ LJETO/SUMMER } \\
\hline $\begin{array}{l}\text { NAZIV } \\
\text { RADIONICE/ } \\
\text { WORKSHOPS' } \\
\text { NAME }\end{array}$ & $\begin{array}{l}\text { MATERIJAL/ } \\
\text { MATERIAL }\end{array}$ & $\begin{array}{c}\text { KRATKI OPIS/ } \\
\text { SHORT DESCRIPTION }\end{array}$ \\
\hline Hokus pokus & $\begin{array}{l}\text { Cvijet } \\
\text { (preporučljivo } \\
\text { bijele boje), voda, } \\
\text { boja za hranu }\end{array}$ & $\begin{array}{l}\text { Ovaj pokus ima izuzetno zanimljiv krajnji rezultat. Bijelim } \\
\text { cvjetovima (npr. karanfili ili ivančice) se, uz nekoliko kapi boje } \\
\text { za hranu, može promijeniti boja latica. U vodu se ukapa par } \\
\text { kapi boje i stavi se cvijet. Kako biljka uzima vodu, tako se } \\
\text { mijenja boja latica. }\end{array}$ \\
\hline $\begin{array}{l}\text { Upoznavanje s } \\
\text { korovima }\end{array}$ & $\begin{array}{l}\text { Rukavice, } \\
\text { lopatica }\end{array}$ & $\begin{array}{l}\text { Korovi često uzrokuju razne probleme na usjevima. Međutim, } \\
\text { imaju i svoju pozitivnu stranu. Maslačak je dobar primjer } \\
\text { korova. Iako zna biti neželjena vrsta, može se koristiti i u } \\
\text { prehrani. Isti je slučaj s koprivom. Vrsta koja raste kao korov, a } \\
\text { izuzetno je ljekovita i ukusna. Naravno, u sklopu radionice } \\
\text { nužno je upoznati se s ambrozijom koja alergičarima stvara } \\
\text { velike probleme. }\end{array}$ \\
\hline Biljni terarij & $\begin{array}{l}\text { Staklenke, } \\
\text { supstrat, } \\
\text { kamenčići ili } \\
\text { pijesak, } \\
\text { sukulenti }\end{array}$ & $\begin{array}{l}\text { Sukulenti, biljke koje u svojim kožastim listovima čuvaju vodu, } \\
\text { prilagođene su za tople uvjete. Vole toplinu i sunce, te ih je } \\
\text { zahvalno u ljeto presaditi na vanjske gredice i posude. Osim toga, } \\
\text { moguće je napraviti terariji za sukulente. U stare staklenke stavi } \\
\text { se sloj kamenčića ili pijeska, zatim supstrat za sukulente. Zatim } \\
\text { idu sukulenti. Čuvarkuća i aloa su dobar izbor, zbog atraktivnog } \\
\text { izgleda i ljekovitosti. Sukulenti zahtjevaju minimalno vode, zato } \\
\text { su zahvalni za ljetne mjesece kada nema učenika u školi. }\end{array}$ \\
\hline
\end{tabular}


Vesna Židovec i sur.: Odabir biljnih vrsta za školski vrt i plan vrtlarskih aktivnosti u OŠ Rugvica

\begin{tabular}{|c|c|c|}
\hline Mini sukulenti & $\begin{array}{c}\text { Matična biljka, } \\
\text { maramica, } \\
\text { posuda sa } \\
\text { supstratom }\end{array}$ & $\begin{array}{l}\text { Od matičnog sukulenta moguće je dobiti male sukulente. } \\
\text { Zanimljiv primjer razmnožavanja biljke reznicama. Odvoji se } \\
\text { zdravi list, koji se odloži na maramicu } 24 \text { sata kako bi nastalo } \\
\text { zadebljanje. Nakon toga list se odloži na površinu supstrata } \\
\text { kako bi se razvilo korijenje. Da bi došlo do toga, list treba } \\
\text { čuvati na temperaturi od } 15 \text { do } 20 \text { stupnjeva, što znači da će se } \\
\text { trebat osigurati hladnija prostorija. }\end{array}$ \\
\hline Izrada tinte & $\begin{array}{l}\text { Latice crvene } \\
\text { pelargonije, voda, } \\
\text { staklena posuda, } \\
\text { aluminij u prahu }\end{array}$ & $\begin{array}{l}\text { Latice pelargonije u lijepoj crvenoj boji mogu poslužiti za } \\
\text { izradu tinte. U vodi se kuhaju latice desetak minuta. Što je } \\
\text { manje vode, to je boja intenzivnija. Aluminij u prahu se može, } \\
\text { ali i ne mora dodati. Ako se dodaje, otopi se žličica u vrućoj } \\
\text { vodi i doda se u vodu s laticama. Aluminij čini boju } \\
\text { dugotrajnijom i intenzivnijom. Na kraju se latice procjede i } \\
\text { dobivena tekućina se prelije u malu staklenu posudu. }\end{array}$ \\
\hline Mirisni paketići & $\begin{array}{l}\text { Tkanina, vrpca, } \\
\text { sušena lavanda }\end{array}$ & $\begin{array}{l}\text { Iako je lavanda mediteranska biljke, sve više se uzgaja na } \\
\text { kontinentu. Vrećice od tkanine, koje su jednostavne za izradu, } \\
\text { napune se sa suhom lavandom. Osim mirisnih paketića, } \\
\text { zanimljivi su i mirisni snopovim. Snop lavande se poveže } \\
\text { trakicom. Osim dekoracije, osvježava prostor i drže nepoželjne } \\
\text { goste dalje od ormara. }\end{array}$ \\
\hline $\begin{array}{l}\text { Osvježavajući } \\
\text { napitak }\end{array}$ & $\begin{array}{c}\text { Limun, voda, } \\
\text { začinsko bilje, } \\
\text { vrč }\end{array}$ & $\begin{array}{l}\text { Kada krenu vrućine, nužno je piti puno tekućine. Voda je } \\
\text { najbitnija, ali može biti i najzanimljivija kada sami učenici } \\
\text { oplemene sa začinskim biljkama. U vrč se ulije voda. Limun, iz } \\
\text { organskog uzgoja, se nareže na kriške i par listića mente se } \\
\text { ubace u vrč s vodom. Da bi se voda aromatizirala, potrebno je } \\
\text { ostaviti preko noći. Naravno, nije nužno da se koristi samo } \\
\text { limun i menta. Osim limuna i mente, mogu se korisiti i drugi } \\
\text { sastojci: krastavci, bobičasto voće, matičnjak, itd. }\end{array}$ \\
\hline
\end{tabular}

\section{ZAKLJUČCI}

Na temelju istraživanja provedenog na području općine Rugvice može se zaključiti da se živjelo prvenstveno od poljoprivrede. Uzgajale su se povrtne i voćne vrste. Osim utilitarnih vrsta, stanovnici se sjećaju i raznolikog ukrasnog bilja u vrtovima, koje je tad ipak teže nalazilo mjesto zbog isključivo dekorativne svrhe. Prisjetili su se i nekih običaja uz koje ih određena ukrasna vrsta veže. Rugvica je kraj bogate tradicije i povijesti, koju valja održavati i danas.

Na području OŠ Rugvica determinirano je 17 porodica i 28 vrsta. Porodice Pinaceae i Lamiaceae imaju najveći broj vrsta. Prevladavaju visoka stabla kao soliteri, u manjim skupinama ili drvoredu. Školsko dvorište ima zanimljive detalje poput sjenice, meteorološke kućice i visećeg vrta na ulazu u školsko dvorište. 
Predložene su vrste za školsko dvorište. Gredice se dijele na: povrtnu, voćnu, začinsko-ljekovitu i tradicionalno-cvjetnu. Shodno tome, birane su predložene vrste. Predloženo je 10 povrtnih vrsta, 9 voćnih vrsta, 10 začinskoljekovitih vrsta i 25 cvjetnih vrsta.

Cjelogodišnji program radionica je podijeljen prema sezonama: jesenske, zimske, proljetne i ljetne radionice. Smisao radionica je da budu zabavne i edukativne $\mathrm{u}$ isto vrijeme. Materijali koji su potrebni za izvođenje istih se najčešće mogu pronaći u školskom vrtu ili bližem okolišu. Zamisao radionica je da učenici razvijaju ekološku svijest i da se povežu s prirodom. Kao izuzetno bitan segment ističe se upravo reciklaža i korištenje materijala koji su ekološki prihvatljivi.

\section{LITERATURA}

1. Anđić, D. (2016). Školski okoliš u funkciji odgojno-obrazovne prakse rada učitelja u odgoju i obrazovanju za održiv razvoj. Školski vjesnik, Vol. 65., No.2, $287-300$

2. Arendt, H. (2014). Naturgeschenke - 100 Ideen zum Gestalten mit Kindern. Hupt Verlag, Bern

3. Benyovsky Šoštarić, K. (2013). Mala vrtlarica. Školska knjiga, Zagreb

4. Bogut, I., Popović, Ž., Mikuška, A. (2017). The role and importance of outdoor teaching and fieldwork in biology for primary school teacher education. Život i škola, Vol. 13, No. 2, 127 - 133, Osijek

5. Borić, E. (2009). Priručnik za nastavu: Istraživačka nastava prirode i društva. Učiteljski fakultet u Osijeku.

6. Božurić, V. (2018). Školski vrtovi u Turopolju - stanje i perspektive. Diplomski rad. Sveučilište u Zagrebu, Učiteljski fakultet. Odsjek za učiteljske studije (Petrinja).

7. Brickell C. (2006). Encyclopedia of Plants and Flowers. Royal Horticultural Society. Dorling Kindersley, Fourth Edition, London.

8. Bull, J. (2003). The gardening book. Dorling Kindersley Publishers Ltd, London

9. Cmrečnjak - Majstorić M. (2016). Edukativno - rekreacijski radni vrt u dječjem vrtiću. Diplomski rad. Sveučilište u Osijeku. Fakultet za odgojne i obrazovne znanosti

10. De Zan, I. (1999). Metodika nastave prirode i društva. Školska knjiga, Zagreb 
Vesna Židovec i sur.: Odabir biljnih vrsta za školski vrt i plan vrtlarskih aktivnosti u OŠ Rugvica

11. FCD (2004). Flora Croatica Database <https://hirc.botanic.hr/fcd/>. Pristupljeno 20. kolovoza 2018.

12. Geoff, B. (2004). Botanica: the illustrated A - Z of over 10,000 garden plants and how to cultivate them. Könemann, Königswinter.

13. Godišnji plan i program rada za školsku 2017./2018. godinu (2017). Republika Hrvatska, Zagrebačka županija, OŠ Rugvica

14. Grudiček - Kozjak, J., Klarić, LJ., Pazman, B., Vusić, K. (2005). Preporučene vrste biljaka za školski okoliš. Agronomski glasnik 2 - 4, 159 - 170

15. Horvatić, K. (2018). Hortikulturna flora predškolskih i školskih institucija na području grada Zaprešića. Diplomski rad. Sveučilište u Zagrebu. Agronomski fakultet.

16. Jambrek, I. (2017). Vrtovi odgojno-obrazovnih institucija na području gradske četvrti Novi Zagreb. Diplomski rad. Sveučilište u Zagrebu. Agronomski fakultet

17. Kirin, M. (2016). Posavski zapisi. Pučko otvoreno učilište Dugo selo, Dugo selo

18. Kolar-Dimitrijević, M. (2014). Značenje školskih vrtova u sjevernoj Hrvatskoj u vrijeme Austro-Ugarske Monarhije. Ekonomska i ekohistorija, Vol. 10(1), $217-232$, Zagreb

19. Leitzgen, A. M., Ehling, T., Drews, J. (2013). Meine gartenwerkstatt. Gerstenberg Verlag, Hildesheim

20. Lukaš, M. (2008). Ekologijski odgoj u školskim vrtovima 19. stoljeća. Cjeloživotno učenje za održiv razvoj. Sveučilište u Rijeci, Učiteljski fakultet u Rijeci, 295-300

21. Munjiza, E. (2003). Pedagogijska funkcija školskih vrtova. Hrvatski pedagoško - književni zbor, ogranak Slavonski Brod Teka d.o.o. Velika Kopanica

22. MZOS (2006). Nastavni plan i program za osnovnu školu. MZOS, Zagreb

23. Ogrizović, V. (1982). Enciklopedija vrtnog bilja. OOUR GLOBUS, Zagreb

24. Općina Rugvica < https://www.rugvica.hr>. Pristupljeno 15. kolovoza. 2018.

25. Pirić, T. (2016). Vrtovi odgojno - obrazovnih institucija na području gradske četvri Sesvete. Diplomski rad. Sveučilište u Zagrebu. Agronomski fakultet

26. Pirnat, S. (1952). Školski vrt. Školska knjiga, Zagreb

27. Schwab, E. (1877). Školski vrt: prinos za riešenje zadatka o javnom odgoju. Zemaljska vlada Kraljevine hrvat. slavon. dalmat. Odjel za bogoštovje i nastavu.

28. Sherman, J. (2010). A new deal for school gardens. FAO, Rim, Italija 
Vesna Židovec i sur.: Odabir biljnih vrsta za školski vrt i plan vrtlarskih aktivnosti u OŠ Rugvica

29. Skulj, A. (1954). Šolski vrt. Državna založba Slovenije, Ljubljana

30. Slačanac, I., Munjiza E. (2007). Programski sadržaj razredne nastave i mogućnost njihove realizacije u školskim vrtovima. Život i škola, Vol 3., No. 17., 87 - 100, Osijek

31. Thörn (2016). Rastimo zajedno. Inter IKEA Systems B.V.

32. Tommes, S., Roß, T. (2002). Velika knjiga vrtlarstva. Golden marketing, Zagreb

33. Trstenjak D. (1883). Školski vrt u selu. Hrvatski pedagogijsko - književni zbor, Zagreb. 1-6

34. Yu, F. (2012). School garden sustainability: Major challenges to the long-term maintenance and success of school garden programs. Faculty of the University of Delaware

Adresa autora - Author's address:

Vesna Židovec, e-mail: vzidovec@agr.h

Silvija Jusup

Miroslav Poje

Dubravka Dujmović Purgar

Sveučilište u Zagrebu Agronomski fakultet,

Svetošimunska cesta 25, 10000 Zagreb, Hrvatska
Primljeno - Received:

15.02.2020. 
Vesna Židovec i sur.: Odabir biljnih vrsta za školski vrt i plan vrtlarskih aktivnosti u OŠ Rugvica 